\title{
Japanese-Style Capitalism
}

\author{
Kazuo Sato
}

Working Paper No. 166 


\begin{abstract}
Japanese-style capitalism is a collusive system of national politics, elite bureaucracy, and big business. Elaborated in the course of rapid growth, it served Japan's post-war economic growth in flying colors. But on-going structural changes, induced by growth slowdown and population aging, now places Japanese-style capitalism in jeopardy. In this paper, we review these changes in the near past - changes in the microeconomic sphere such as the family system, the employment system and the business system and changes in the macroeconomic sphere such as increasing parttime work in the labor market, slowdown in technical change, decline in manufacturing at home, persistence of trade surplus, and ongoing financial deepening.
\end{abstract}




\section{Japanese-Style Capitalism}

\section{The Genesis}

The reader may have wondered why the author has gone back in history to 1868 when he is supposed to be looking at the contemporary economy. The reason for the history is I wanted to show that-in an essential sense-the command mechanism of Japan's economic system has not changed despite some major changes over the years in the economic system. The Japanese economy is still ruled top down. The ruling class (top) rules the country from above, and the masses (down) obey the orders from above. Though the top has changed a number of times, the basic scheme has not.

In the Tokugawa period (1600-1867), the ruling class was the military (samurai) class. ${ }^{1}$ The Tokugawa feudalism collapsed because, although the government was based on an agrarian economy, the economy itself became increasingly monetized with the consequent rise of the merchant class in economic power.

The Meiji Restoration, which followed the Tokugawa regime, however, was not a revolution in the sense of a revolt of the masses. Government leadership was merely handed over from one segment of the samurai class to another. Though the country was centralized and the economy was turned into a capitalist system, the ruling over the country was still conducted from above. On the top, civilians and militarists were interchangeable because they both came from the same roots. Thus, the government of bureaucracy-military continued until the end of World War I. Then parliamentary democracy was the form of government that ruled for a while in the 1920s, but militarism again usurped the top. In the meantime, zaibatsu firms came to the fore, and eventually the military-zaibatsu coalition led the country into a catastrophic war.

Japan was defeated in the Pacific War, and a new governmental system was introduced in 1945. The postwar reform was an attempt by the Americans to remake Japan in their ideal image by transplanting American institutions. The military was eliminated, zaibatsu families were liquidated, big zaibatsu firms were broken up, tenant farmers were given the land on which they worked, women were given equal rights, and workers were encouraged to form unions. Japan was supposed to be turned into a democracy by the political participation of the common people.

After the Americans left, these changes were modified to a large extent, even 
though some were not to be undone (e.g., the loss of wealth by the zaibatsu families and the economic independence gained by tenant farmers). However, the split zaibatsu firms regrouped themselves into a new form of business groups, called keiretsu, without zaibatsu families.

Unions did not become American-style trade unions but were organized instead as company unions, with the unionization ratio moving straight downward. Women were given equal rights with men on paper, but the actual elevation of their status in society was very slow. Belatedly, the Equal Employment Opportunity Law (EEOL) was adopted in the mid-1980s to encourage women to enter the labor market. The law was supposed to see that women received equal treatment with men, but women are still underpaid and discriminated against in the workplace.

Modifications during the Postwar Reform gave rise to Japanese-style capitalism, which refers to the basic makeup of the contemporary economic system of Japan, especially its command mechanism. This Japanese-style capitalism is still top down, although the composition of the top has changed because of the postwar reform. During the wartime and the immediate postwar confusion, the national economic management was entrusted to the elite bureaucracy which gained even more political power. Then, the postwar reform eliminated the military and instead placed politicians in Japan's command mechanism.

The Diet, especially the House of Representatives, elects the prime minister who is in charge of national-level policy-making. However, contrary to the original American intention, political power was continually monopolized by the Liberal Democratic Party (LDP) for thirty-eight years from its creation in 1955 to its fall in 1993. Then, the keiretsu (the reborn zaibatsu) claimed full membership in the top. Thus, the postwar economic growth was carried out by big business. Naturally, these big businesses wanted their clout fully reflected in national economic policy. Therefore, the command mechanism of Japanese-style capitalism became the triad of elite bureaucracy, national politicians, and big business. Japan is still governed by the few.

The three parties of the triad help one another. National politicians depend greatly on contributions by big businesses to support their expensive election campaigns. Big business, in turn, expects to be paid back in the form of special favors. Politicians also depend heavily on the expertise of elite bureaucrats during policy-making. By exercising their power in the enforcement administrative regulations (which abound in Japan), bureaucracy can give favors to big businesses. In their later careers, elite bureaucrats either enter national politics or find employment in big business.

When the three parties are interdependent in this give-and-take of favors, each can increase its own utility. In other words, this is not a zero-sum game but a positive-sum game. The give-and-take among the players also means that the triad is a quasi-permanent arrangement because the exchange of favors goes 
beyond the short term and the maintenance of the triad is costly. This is why Japanese-style capitalism has continued for so long. ${ }^{2}$

Though the triad itself is a positive-sum game within itself, its trade with the rest of the economy is a zero-sum game; that is, the gains of trade by the triad must come from somebody else's losses. ${ }^{3}$ This "somebody else" is the consumers and the small businesses.

Needless to say, each member of the triad is a group of its own members. When we present such a group as an independent entity, we assume that the group has already succeeded in reconciling any conflicts of interest among its members. This, as we shall argue below, is the maximization of the group's collective utility. This exercise in reconciliation requires the establishment of a certain control mechanism within each group. In politics, the dominance of the LDP solved this problem of interest aggregation. Within the bureaucracy, the Ministry of Finance usually plays the leading role because of its budget allocation power, although the Ministry of International Trade and Industry (MITI) wants equal rights from time to time. In the business group, each keiretsu group organizes its hierarchical structure and a market-sharing agreement is made among keiretsu groups to avoid open competition.

\section{The Principle of Collective Utility Maximization}

Let us offer a somewhat more theoretical discussion about the reasons why and how members of the triad participate in the give-and-take game. For this exercise, it is useful to apply the prisoners' dilemma game from game theory.

There are two players in the prisoners' dilemma game. When they do not cooperate, the outcome is a poor solution; when they do cooperate, they both gain; that is, this is a positive-sum game. In reality, payoffs are not single numbers but vary according to the amount of cooperation among the players. Each player decides how much cooperation he will offer and how much he should get back from the other player. Since their interests are at odds with each other, an arrangement must be made through mutual negotiations to settle these conflicts of interest. Needless to say, the settlement depends on how strong each player is relative to the other player.

Given their relative strengths, the settlement mechanisms can be analytically described as the maximization of the two players' collective utility. The application of a standard utility analysis shows that the necessary condition for collective utility maximization is the equality of the marginal rates of substitution in favors given by the two players.

However, there are many combinations of these favors that satisfy the necessary condition. Which combination is chosen is determined by the maximization of the two players' collective utility. In turn, this determination depends on the players' relative power. We must also note that it is costly to settle these con- 
flicts of interest between players. To recoup the cost, the settlement arrangement must be made quasi-permanent; that is, the settlement will last as long as the payoffs are sufficiently beneficial. ${ }^{4}$ It will begin to collapse when payoffs are less advantageous (see Appendix I for a more formal analysis). ${ }^{5}$

When there are three players with differing objectives, the game often becomes more complex. However, we can still visualize the game as the maximization of the three players' collective utility. The game can continue quasi-permanently as long as each player remains robust. In a true democracy, the weak link may be thought to be politics because the ruling party can change so often.

Japan solved this problem by placing the LDP in the ruling position semipermanently. The LDP seemed to be so secure in maintaining its ruling position that it came as a great shock when the LDP lost its majority in the Lower House in the July 1993 general election. A fundamental political reform seemed to be in the offing when the cabinet was formed by a non-LDP coalition. Unfortunately, this hope for reform was short-lived. Within a year, the LDP came back-though it received help from other parties, especially the Japan Socialist Party (JSP).

As we noted, the triad makes its gains by "exploiting" the rest of the economy (i.e., small businesses and consumers). This exploitation can take various forms. For example, it can be disguised as the workings of the free-market mechanisms. In the case of small businesses, the form is the dual structure which is characterized by large, interfirm wage differentials (Sato 1995c). Consumers are exploited via high consumer prices relative to the low prices of producer goods, especially by the prices charged by large firms.

The government has followed a pro-producer (more exactly, a pro-big business) policy rather than a pro-consumer policy. The high price of rice was a symbol of the government's attitude. The differential between domestic prices and foreign prices $-a$ hot issue in Japan for the last several years - concentrates on consumer prices. Amazingly, an outcry by the consumers about inequity has remained muted because groups representing consumer interests are still disorganized. So-called consumer organizations even gave express support to the government's policy of banning rice imports.

The government pacifies consumers by pointing out that the tax burden on individuals is very low in Japan as compared to other developed countries and the income inequality in Japan is the lowest among people of the world. People are told, time and again, that they should feel content because they are given a fair shake. As long as people accept this, the triad can continue on its own way.

\section{Collective Utility and Long-Term Relationships}

We have observed that the maximization of collective utility for the triad helps to make it a quasi-permanent relationship. The same observation can be made on the micro level whenever a group is formed. Such groups can be very basic 
economic units (i.e., the household and the firm). They can also be groups of households (i.e., the community) or groups of firms (as in the keiretsu groups). All of them are engaged in maximizing their collective utilities, and they are bound together by long-term economic relationships. Indeed, these long-term economic relationships are a defining characteristic of Japanese-style capitalism. Although the subject has been discussed on numerous occasions, let us consider a few examples below.

The Japanese family places a great deal of value on the education of its children and is willing to sacrifice the interests of individual members for that objective. Adult family members even refrain from divorce so as not to harm the children's welfare. Apparently, the collective utility of the family is more important than the utility of individual members, and this entails durability of the Japanese family.

The Japanese firm, especially the big firm, is another example. Lifetime employment is practiced for its core male employees. An employee, in turn, devotes his whole life to the firm. The collective utility of the firm overrides the individual utility of any single employee. Thus, employees stay in long-term relationships with their employer.

Long-term relationships can also exist at higher levels (e.g., a group of firms). Subcontracting agreements between buying and selling firms are quasi-permanent in Japan (unlike agreements in the United States which are predominantly short-term). This is because, in Japan, both subcontractees and subcontractors are interested in securing long-term profits which can be ensured by maintaining subcontracting agreements on the long-term basis.

Keiretsu is another quasi-permanent relationship among member firms of a keiretsu group. Member firms are supposed to benefit from dependence on other member firms. Mutual ties among them are made more permanent by various arrangements, including cross-firm share ownership, interchanges of executives, and a sales-financing network within the keiretsu group.

In all these instances, the collective (whether it be the family, the firm, or the keiretsu) has its own utility to maximize. The members of a collective must subjugate their individual utilities for the sake of the collective utility. These actions require long-term relationships among the members of the collective. Thus, members stay in the collective because they believe that their short-term losses will be compensated by their long-term gains. Parents put up with the high cost of rearing children because they expect to be compensated for it by the eventual satisfaction of a job well done. Employees stay with the same employer for their "lifetime" because they expect to be rewarded by higher wages in the latter part of their careers. Keiretsu firms stay in the same group because they can rely on assistance from the group in times of exigency.

The maximization of collective utility and long-term relationships goes handin-hand. If one breaks down, the other also falls. 


\section{In Versus Out}

When a collective is organized on the long-term basis, the collective is pitted against other collectives. Members of a collective consider themselves to be insiders and discriminate against members of other collectives as outsiders. The in-versus-out distinction is another well-known characteristic of Japanese society. When the distinction is strong, society tends to be fractionalized. Therefore, the staff in a Japanese firm is often divided into factions each vying for the company's presidency. The LDP has been a party of several factions; the party presidency is elected from among these various factions. Sociologist Chie Nakane (1970) called it "vertical society."

However, the in-versus-out distinction is multilevel. Who is viewed as the outsiders depends on from what level the outsiders are being considered. Within a faction, members of other factions are outsiders even though they all belong to the same firm. However, when the members are considered on the keiretsu level, all the firms in the keiretsu group are insiders, and all other firms are outsiders. Finally, at the national level, all Japanese nationals are insiders and all foreigners are outsiders.

The point here is that the in-versus-out distinction is a natural corollary of the collective that maximizes its joint utility. Thus, it permeates throughout the Japanese society and economy.

\section{Notes}

1. This system started in 1165 when the Taira family, a royal descendant, replaced the civilian government of the Fujiwara family (894-1164). Since then, though the ruling family has changed a number of times, the system has remained the same. The Tokugawa rule is notable in that its rule extended over the entire nation. The Tokugawa set up a desentralized command system in which local domains were ruled by individual lords while all lords were under the command of the central government of the shogun.

2. The idea of the triad has been used in the popular press, but has not been given full attention by academicians, as Okumura (1995, chap. 1) observes. See Okumura (1995) for an explicit, qualitative assessment of the triad thesis with many references on the subject. (Okumura has been writing on the subject for the last twenty years.)

3. In the "Japan, Inc." thesis, the government acts as the head office of a joint-stock company and big businesses as its operational departments to pursue the export-or-perish policy. This thesis is said to have been put forth in a U.S.-Japan business conference held in Washington, D.C. in June 1971. At this conference, American business executives criticized Japan's national economic policy. See Kaplan (1972) on this thesis. For the rejection of this thesis by Japanese economists, see Komiya et al. (1988), especially Tsuruta (p. 58) who notes that it is not government intervention but the market mechanism that supported the rapid growth of the 1960s.

4. When the LDP stepped down after the general election of July 1993, the political contributions it received also fell.

5. The "power theory" has been espoused by many economists in the past. In Japan, Yasuma Takata (1885-1972) put forth such a theory fifty years ago (Takata 1947). 


\section{Recent Changes}

Japanese-style capitalism, which had been brought to fruition in the rapid growth period, started to be eroded in the slow growth period because of various significant economic changes in recent years that, of necessity, have affected Japan's economic institutions. In what follows, our review of these recent changes is divided into microeconomic and macroeconomic changes though the distinction is rather arbitrary. The recent history is also loosely defined. How far we look into the past varies from case to case.

\section{Microeconomic Changes}

\section{The Family System and Demography}

\section{The Family Structure}

The traditional family structure in Japan was, as is common in Eastern society (Asia and Africa), the three-generation family. That is, the second generation of working age supports the first generation in retirement and nurtures the third generation. By destroying the concept of the ie (family), the Postwar Reform was supposed to phase out the three-generation family. Indeed, three-generation families were on a rapid decline between 1955 and 1995, as shown in Table 1 (column 2b). This decline is matched by a rapid increase in single-person households (column 3 ) while the percentage of nuclear families (column 1) remained stable. However, in both columns (1) and (3), parents who are older (sixty-five and over) increased (columns la and $3 a$ ). When all sixty-five and over parents are added together, the total number (column 4) fell at first but tumed upward after 1975. The year 1975-the beginning of the slow growth period-serves as the turning point for long-term changes of the family structure.

\section{Demographic Changes}

Behind the changes in the family structure, there have also been demographic changes. People are living longer and young people are marrying later and having fewer children. The average family size continues to decline, from 5.0 persons in 1955 to 2.9 persons in 1995 . The standard family is now two young parents and a child. The birth rate has been declining steadily from 1.5 percent in 
Table 1

The Family Type, Percent of Total

\begin{tabular}{lccccccccccc} 
& $(1)$ & $(1 \mathrm{a})$ & $(2)$ & $(2 \mathrm{a})$ & $(2 \mathrm{aa})$ & $(2 \mathrm{~b})$ & $(2 \mathrm{ba})$ & $(3)$ & $(3 \mathrm{a})$ & $(3 \mathrm{~b})$ & $(4)$ \\
\cline { 2 - 11 } 1955 & 59.6 & - & 36.5 & 2.6 & - & 33.9 & - & 3.4 & - & - & - \\
1960 & 60.2 & 3.5 & 34.7 & 2.5 & 0.8 & 32.2 & 17.2 & 4.7 & 1.0 & 3.7 & 22.5 \\
1965 & 62.5 & 4.2 & 29.8 & 2.4 & 1.0 & 27.4 & 15.6 & 7.9 & 1.2 & 6.7 & 22.0 \\
1970 & 63.5 & 4.7 & 25.4 & 1.3 & 0.8 & 24.1 & 14.5 & 10.8 & 1.4 & 9.4 & 21.4 \\
1975 & 59.5 & 5.3 & 20.8 & 1.5 & 1.1 & 19.3 & 12.4 & 15.5 & 1.9 & 13.6 & 20.7 \\
1980 & 60.3 & 6.5 & 19.9 & 1.7 & 1.3 & 19.2 & 12.4 & 19.8 & 2.5 & 17.3 & 22.7 \\
1985 & 60.0 & 7.5 & 19.0 & 1.8 & 1.4 & 17.2 & 12.2 & 20.8 & 3.1 & 17.7 & 24.9 \\
1990 & 59.6 & 9.3 & 17.1 & 1.9 & 1.6 & 15.2 & 11.4 & 23.1 & 4.0 & 19.1 & 26.4 \\
1995 & 59.1 & 12.0 & 15.8 & 2.0 & 1.7 & 13.8 & 10.9 & 24.8 & 5.2 & 19.6 & 29.9
\end{tabular}

Source: The Census of Population.

Notes:

(1) Nuclear family

(1a) Column (1) with parents 65 and over

(2) Other relatives family

(2a) Two-generation family

(2aa) Column (2a) with parents 65 and over

(2b) Three-generation family (including others)

(2ba) Column (2b) with parents 65 and over

(3) One-person household

(3a) Column (3) age 65 and over

(3b) Column (3) otherwise

(4) Parents 65 and over, total columns (1a) $+(2 \mathrm{aa})+(2 \mathrm{ba})+(3 \mathrm{a})$

the early 1970 s to 1.0 percent now. The death rate also declined from 0.5 percent to less than 0.3 percent. Consequently, the population growth rate declined from 1.1 percent to 0.7 percent.

The decline in the birth rate is also related to the decline in the reproduction rate for females. Their total fertility rate was about 4 until 1949 and settled to approximately 2 between 1958 and 1975 . After 1975 the fertility rate declined toward 1.8. It started to decline again after 1984, passing the level of 1.5 in 1992.

The total fertility rate for females has been declining because females are marrying later or not at all. This is seen in the long-term changes in the marriage ratio (new marriages : population). After it peaked at 1.2 percent in 1947-48 (compensating for the war), it declined to around 0.8 percent between 1952 and 1956. Then it started to rise through the rapid growth period and peaked at 1.04 percent in 1972-73. It declined again to around 0.6 percent after 1984 to the present-this is an all-time low.

The same point is clearly seen in the population distribution (aged fifteen and 
over) by marital status (Table 2). For both males and females, the married status peaked and the unmarried status bottomed out in 1975-80. Since then the married percentage has been declining, and the unmarried percentage has been rising. More striking are the changes in the proportion of people who are divorced. For both males and females, the divorced rate reached its lowest point in 1965; since then the proportion has been inching up, more or less doubling by 1990 .

That people marry later and divorce more often is confirmed by a comparison of 1975 and 1995 (see the lower half of Table 2). The change is most striking in the age range of 25-39. Witness a sharp decline in the proportion of the married, especially in the 25-29 age bracket. People are either marrying later or do not marry at all. The divorced population has also increased over time. For a comparison, we also show changes in the older population in the age range from 60 to 74 . The rise in the divorce rate for this age bracket is notable here as well.

Why do women marry later and have fewer children? One powerful reason is found in the increased educational attainments of females (see below). They now prefer to have more time to be single before marrying and bringing up children. This change in attitude among females occurred in the slow growth period.

\section{Modes of Marriages}

When we examine Japanese marriages and divorces, we should not overlook the biggest change in this area in postwar Japan-namely, how Japanese people find marriage partners. Until the end of World War II, more than 85 percent of the marriages in Japan were via miai (i.e., "interview marriage"). ${ }^{1}$

In the prewar years, boys and girls were segregated in primary schools and there were no coeducational secondary schools. As a general rule, women with higher education did not enter the paid labor force. Thus the opposite sexes had no chance for free association. Marriages had to be "arranged," that is to say, some busybody, old ladies circulated photographs of prospective candidates with short biographies among acquaintances. If a boy and a girl were both willing, a formal, chaperoned get-together was arranged-hence, the name of miai or "see one another." If each party thought the other party was promising, the boy and the girl would consent to a few more dates and then decide whether to continue or discontinue. If they continued, they might eventually reach the goal of marriage.

Thus, though the miai was arranged, the final decision rested with the free will of both parties (though often marriages were forced for family reasons). In Japan's prewar social structure, the miai was the rule. If young people fell in love and decided to marry-often against the opposition of their families-the marriage was considered a violation of the social protocol. If the family was dominant, the romance often ended in a Romeo-and-Juliet type of tragedy (a popular theme in kabuki plays). 
Table 2

The Marital Status by Sex, Population of Age Fifteen and Above

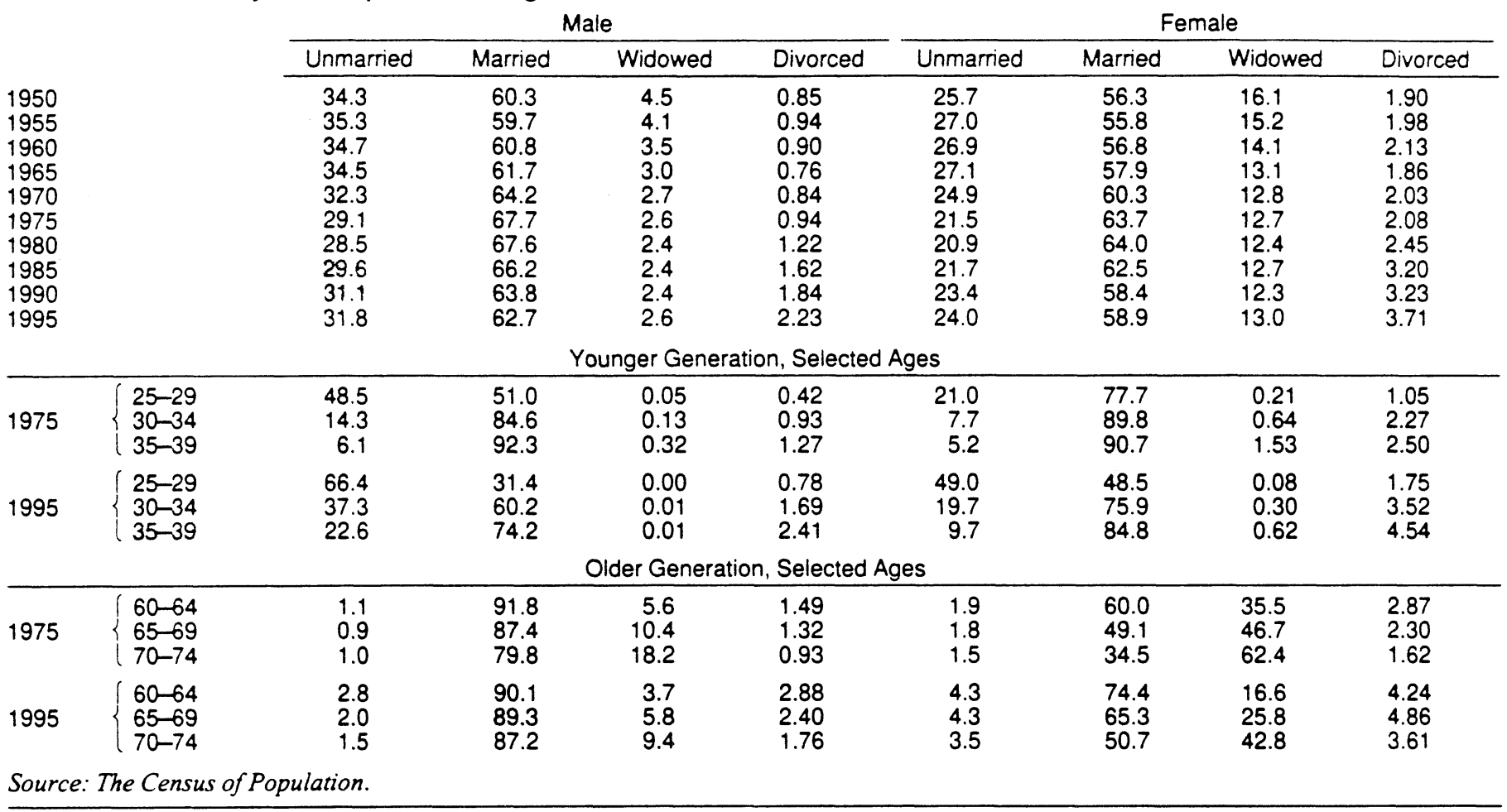


The spread of coeducation and the elevated status of women gave people a strong impetus to repudiate the miai system. The Shussei doko chosa [Vital Statistics Survey], a sample survey conducted every five years (since 1940) by the Ministry of Welfare, inquires about the mode of marriage for newlyweds and arrives at a fascinating result. Miai marriages started at 70 percent in 1940-45 and continued to decline over the years so that by 1992 the level had reached 15.2 percent. "Love" marriages, on the other hand, started at 12.8 percent and rose to 82.8 percent. (These percentages do not equal 100 because there are several percentage points of "no answer.") The two proportions crossed each other between 1965 and 1970. Thus, the late 1960s may be considered a turning point in Japan's marital history. ${ }^{2}$

In the prewar system of miai marriages, the $i e$ had much to say, especially concerning the marriage of its male heir. The family imposed social constraints on its members concerning marriage. In turn, the divorce rate at that time was low (a little less than 0.07 percent). ${ }^{3}$ Has the spread of love marriages changed all this? After all, when people freely choose the person they marry, they can also freely choose to divorce. The divorce rate stayed below 0.08 percent in $1956-66$ but started to inch up thereafter. Since 1984 the divorce rate has been 0.15 percent or thereabouts, but it is still less than in the West. The highest divorce rate is in the United States with 0.45 percent (1993).

However, it would seem that married couples in Japan must be unhappy in their married life as often as couples in the United States. Then why are Japanese couples divorced less often than American couples? There must be some factor at work. One powerful constraint against divorce is the strong propensity by Japanese families toward the maximization of the family's collective utility. We can see it clearly in the Japanese family's response to the education of its children.

\section{Family's Response to the Education of Its Children}

In an egalitarian society, the key factor for a person's advancement in society is his or her educational attainments. The Japanese family is eager to support its children in school from kindergarten to college. In the prewar period, the children receiving educational support were limited to boys, who were expected to be the bearers of the family name; now both boys and girls proceed to college. To gain acceptance to the best colleges, however, they have to prepare for highly competitive college entrance examinations. Therefore, the family must provide a good study environment for the children at home.

In addition, the family believes that children ought not to be disturbed in their formative years. At the time the children are preparing for college examinations, their fathers (if they happen to be employees of big businesses) are often transferred to branch offices of the company far away from home. As junior executives, the fathers cannot afford to refuse assignments. Rather than forcing their 
families to relocate with them, the fathers travel to their new assignments alone.

This is the well-known tanshin funin phenomenon (transfers unaccompanied by family). That is to say, the father sacrifices his own utility for the sake of the family's collective utility because providing his children with a good education is considered of paramount importance in the family utility function. Through the sacrifice endured by the father, the family as a whole achieves a higher level of utility.

Needless to say, there are other economic factors involved in this decision. Another important objective in the family utility function is home ownership. Since the family is still paying off its mortgage, the family has to remain behind while the father works elsewhere.

\section{The Target Is Achieved and the Family Dissolves}

In recent years, the increase in so-called silver-age divorces has attracted public attention; that is, the number of divorces has been rising among couples in the retirement age. This is clear in Table 2 . The proportion of the divorced population among the older generation has been on the increase from 1975 to 1995.

By the time the husband reaches the mandatory retirement age of sixty, the family will have completed its task of raising children and will have paid off its housing loan. The husband may be looking forward to beginning his post-retirement life, but the wife may object to continuing the marriage. She is now relieved of the responsibility of raising children (which rested on her shoulders alone while her husband was at work and away from home), and she hopes for a free life unencumberedered by any further responsibility at home.

Certainly the wife is loath to take care of her husband who, once he is retired, would stay home twenty-four hours a day. She regards the husband as sodai gomi ("big gross rubbish"), a term coined by the press a few years ago. Therefore, she asks for a divorce in which she expects to receive a half share of the husband's retirement benefits.

When the family has achieved its long-term target of maximizing its collective utility, the family itself loses its raison d'être. It is at this point that the family disintegrates. The number of silver-age divorces is still small, but the cases are of interest because it points to a possibility of the Japanese-style system unraveling.

\section{The Employment System}

\section{Lifetime Employment and Mandatory Retirement}

The mandatory retirement age, which was raised from age fifty-five to sixty, was gradually adopted by companies through the 1980s. Now nearly all firms with compulsory retirement set sixty as the mandatory retirement age. ${ }^{4}$ However, 
many male workers want to continue to work beyond the age of sixty. This desire is so strong that the labor force participation ratio (LFPR) of male workers aged sixty-five and over has remained at about 38 percent since the mid-1980s. ${ }^{5}$ A person's life expectancy at birth is currently seventy-six years for males and eighty-three years for females, that is, males who reach the age of sixty can expect to live twenty years more and females, twenty-five years more (1992 Abridged Life Table).

The upward adjustment of the mandatory retirement age is critically related to the fate of the lifetime employment system and the state of the social security system. As is well known, lifetime employment has been the employment system of large firms for regular male employees. Employees were hired by companies when they graduated from school, and they stayed with the company through their "lifetime," that is, until their mandatory retirement. Wages usually rose with continued service, or equivalently, with the worker's age though how much a worker's wage actually increased often depended more on an individual's abilities.

The mandatory retirement age, which is now almost universally set at sixty, was raised from fifty-five in line with the increase in life expectancy. ${ }^{6}$ The age of sixty coincides with the age at which social security benefits can begin, albeit at the reduced rate of 80 percent of full benefits receivable at age sixty-five.

The seniority-related or nenko wages were feasible because the age structure of the work force was of a pyramid type. With the main body of the work force young, large firms could keep the wage cost relatively low even though they paid much higher wages to senior workers, certainly much higher than wages paid by smaller firms.

However, with the aging of the population (see below), the entire wage and retirement structure can no longer be maintained in its present form. There are fewer younger workers and more older workers. The average wage cost is bound to increase if the present age-wage profile is continued. However, the mandatory retirement age of sixty is becoming increasingly unrealistic because there will continue to be more older males in the labor force, and because it is projected that the starting age of social security benefits should now be raised to sixty-five.

The further advance in aging of the Japanese people and the resultant change in the age structure of the population spell the end of the seniority-related wage system and, by the same token, the demise of the lifetime employment system as it is presently constituted. However, older workers expect to live longer, and they must find a way to tide over the five-year gap between the mandatory retirement age and the start of social security benefits. Thus the drive to find paid employment will intensify on the part of older workers-meaning that they have to remain in the labor market. As the supply of younger workers decreases, firms may be more willing than before to hire older workers. Definitely, the employment system must change one way or another. 
Table 3

The Spread of College Education (in percent)

(A) Japan: Students advancing to colleges ( $1-4$ years) from senior high schools

\begin{tabular}{lcccc} 
& 1970 & 1980 & 1990 & 1995 \\
\cline { 2 - 5 } Male & 29.2 & 41.3 & 35.2 & 42.9 \\
Female & 17.7 & 33.3 & 37.4 & 47.6 \\
Total & 23.6 & 37.4 & 36.3 & 45.2
\end{tabular}

(B) Japan: Higher-education graduates' as percent of the population, 15 years and over, and of the labor force

\begin{tabular}{lrrrrc} 
& \multicolumn{3}{c}{ Population } & & Labor force \\
\cline { 2 - 3 } & 1970 & 1980 & 1990 & 1990 \\
\cline { 2 - 4 } Male & 12.0 & 17.4 & 22.1 & \\
Female & 5.1 & 10.2 & 16.1 & & 21.2 \\
Total & 8.4 & 13.7 & 19.0 & & 24.7
\end{tabular}

(C) United States: College educated (1-4 years) as percent of labor force, 25-64 years

\begin{tabular}{lcccc} 
& 1970 & 1980 & 1990 & $1995^{2}$ \\
\cline { 2 - 5 } Male & 27.9 & 42.0 & 47.7 & 55.2 \\
Female & 22.1 & 36.1 & 46.4 & 56.8 \\
Total & 25.9 & 39.6 & 47.1 & 56.1
\end{tabular}

Sources: (A) Ministry of Education, Mombu tokei yoran [Handbook of Education Statistics], 1995, pp. 36-37; (B) The Census of Population; (C) SABUS, 1995, Table 629 and 1996, Table 618.

'Excludes those in attendance.

${ }^{2}$ Definitional changes in 1992. The percentage rose from 1991 (old; definition) to 1992 (new definition) as follows: male (47.8\% to $51.3 \%)$, female $(47.4 \%$ to $51.9 \%)$, and total $(47.6 \%$ to $51.6 \%)$.
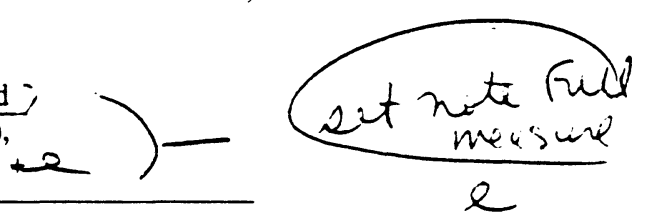

\section{Female Labor Force Participation}

We have argued that the increased educational attainments by females contributed to later marriages and fewer children. Does this also foster an increased labor force participation by females? We examine this point below.

At the present time, most junior high school graduates proceed to senior high school (males, 95.8 percent; females, 97.6 percent, 1995). The percentage of senior high school graduates proceeding to college ( $1-4$ years) is shown in Table 3 for 1970-95.

After World War II, the number of years for compulsory education was raised to nine (i.e., through junior high school). However, at first, the prewar legacy was strong, and far fewer female students advanced to senior high school, not to 
Table 3

The Spread of College Education (in percent)

(A) Japan: Students advancing to colleges ( $1-4$ years) from senior high schools

\begin{tabular}{lcccc} 
& 1970 & 1980 & 1990 & 1995 \\
\cline { 2 - 5 } Male & 29.2 & 41.3 & 35.2 & 42.9 \\
Female & 17.7 & 33.3 & 37.4 & 47.6 \\
Total & 23.6 & 37.4 & 36.3 & 45.2
\end{tabular}

(B) Japan: Higher-education graduates ${ }^{1}$ as percent of the population, 15 years and over, and of the labor force

\begin{tabular}{lrcccc} 
& \multicolumn{3}{c}{ Population } & & Labor force \\
\cline { 2 - 3 } & 1970 & 1980 & 1990 & 1990 \\
\cline { 2 - 4 } Male & 12.0 & 17.4 & 22.1 & 27.2 \\
Female & 5.1 & 10.2 & 16.1 & 21.0 \\
Total & 8.4 & 13.7 & 19.0 &
\end{tabular}

(C) United States: College educated (1-4 years) as percent of labor force, 25-64 years

\begin{tabular}{lcccc} 
& 1970 & 1980 & 1990 & $1995^{2}$ \\
\cline { 2 - 5 } Male & 27.9 & 42.0 & 47.7 & 55.2 \\
Female & 22.1 & 36.1 & 46.4 & 56.8 \\
Total & 25.9 & 39.6 & 47.1 & 56.1
\end{tabular}

Sources: (A) Ministry of Education, Mombu tokei yoran [Handbook of Education Statistics], 1995, pp. 36-37; (B) The Census of Population; (C) SABUS, 1995, Table 629 and 1996, Table 618.

${ }^{1}$ Excludes those in attendance.

${ }^{2}$ Definitional changes in 1992. The percentage rose from 1991 (old ; definition) to 1992 (new definition) as follows: male (47.8\% to $51.3 \%)$. female $(47.4 \%$ to $51.9 \%)$, and total $(47.6 \%$ to $51.6 \%)$.

\section{Female Labor Force Participation}

We have argued that the increased educational attainments by females contributed to later marriages and fewer children. Does this also foster an increased labor force participation by females? We examine this point below.

At the present time, most junior high school graduates proceed to senior high school (males, 95.8 percent; females, 97.6 percent, 1995). The percentage of senior high school graduates proceeding to college ( $1-4$ years) is shown in Table 3 for 1970-95.

After World War II, the number of years for compulsory education was raised to nine (i.e., through junior high school). However, at first, the prewar legacy was strong, and far fewer female students advanced to senior high school, not to 
mention to college. However, as the economy entered the rapid growth period of the 1960s, the proportion of students attending senior high school rose to nearly 100 percent for both males and females. At that time, females started to advance to college - though still at a rate much lower than males.

However, as Table 3 indicates, the college advancement ratio for males peaked around 1980 and then began to decline through the 1980s. The ratio, however, started rising once again after 1990. In contrast, advancement to college for females continued to increase with no interruption; thus, by the late 1980 s, there were more female college students than male students.

However, this point needs one qualification. While most of the male students go to four-year colleges, two-thirds of the female students attend junior colleges. Increasingly now, though, more female students opt for four-year colleges. Also, the female students are no longer confined to their favorite "soft" departments in college such as English literature or home economics. They are increasingly enrolled more in "hard" departments such as science, technology, and medicine. In turn, when female students receive professional training, they endeavor to enter the professional fields for employment.

Female employees used to be discriminated against in the workplace because employers assumed that they would not remain with the company for a career but would quit when they married in their mid-twenties. However, later marriages or no marriages mean that females are now more intent on striving for careers. In 1985, the government finally adopted the Equal Employment Opportunity Law (EEOL) to improve working conditions for female workers. While the law is alleged to have contributed to the advancement of female employment, ${ }^{7}$ the depressed economy in the early 1990s has worked against female entrants into the labor market. Although the overall percentage of college graduates finding employment at graduation has decreased, female graduates have been affected more adversely than male graduates. ${ }^{8}$ The law is apparently not powerful enough to fight against macroeconomic forces.

Changes in the labor force participation ratio (LFPR) for females are shown in Table 4. We note first that the LFPR for males has been on a downward trend as the result of two effects. First, the increased schooling of young people tended to reduce their availability as a labor supply and, second, the continued withdrawal of older workers from the labor market (until the mid-1980s).

However, we found the LFPR for females was behaving differently. At first, their LFPR declined through 1975. This is a reflection of the continued shrinkage in the agricultural sector since more women participated in this type of work than in urban industries. As agriculture sufficiently shrank, this effect disappeared. Then, as more females became better educated, they started to join the labor market. Hence, their LFPR has been rising. ${ }^{9}$

However, this increase is very modest, and it is small indeed when compared with the increase in college-educated women. A comparison with the United States is instructive. As shown in Table 3, the number of college-educated 
Table 4

The Labor Force Participation Ratio (LFPR) by Sex (in percent)

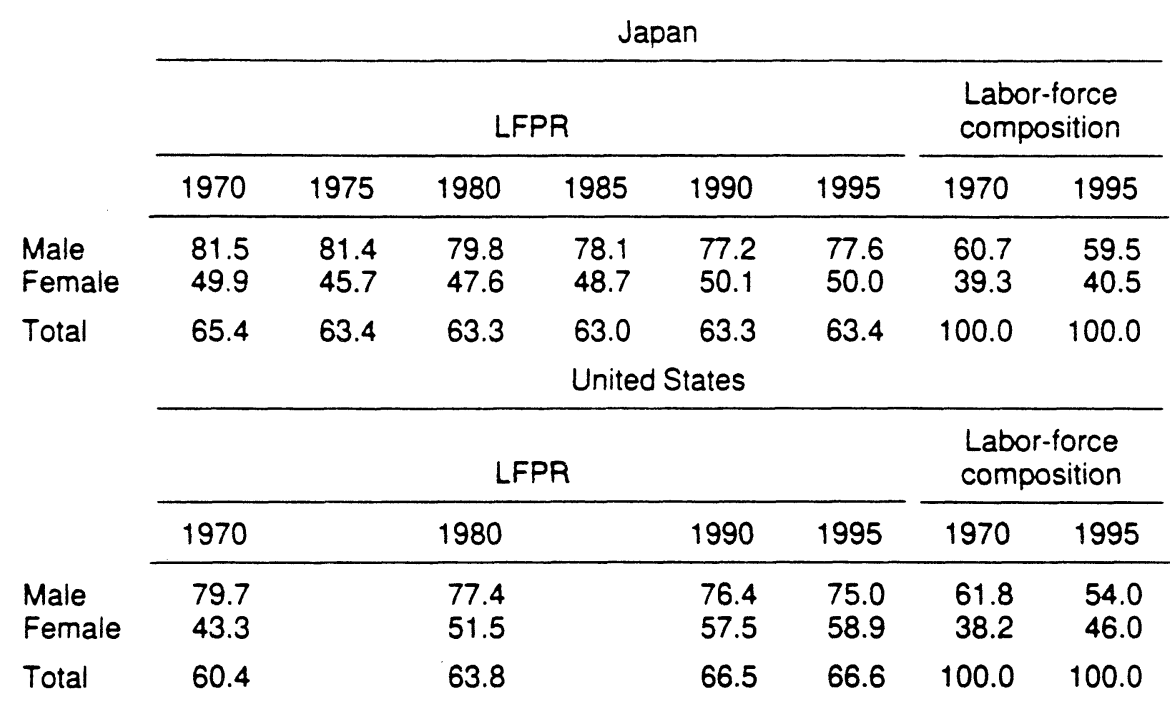

Sources: Japan: Prime Minister's Office, Labor Force Survey; United States: SABUS, 1996, Table 615.

women has increased in the United States as well. In the United States, however, the increased number of college graduates is matched by a substantial increase in the female LFPR.

The difference between female employment in the United States and Japan is clearly reflected in changes in the labor force composition by sex. In 1970, the labor force in both countries was divided into nearly equal proportions - six males for every four females. A quarter century later, the labor force composition has hardly changed in Japan, but it is now five males for every five females in the United States. This is clear evidence that, in the United States, more of the better educated women enter the labor market. Why not Japanese women?

The question here boils down to the following: Is the failure to increase educated women in the labor supply due to supply-side or demand-side factors? In other words, are Japanese girls attending college only for enjoyment and not for careers, or are Japanese employers unwilling to hire educated women? The answer seems to be the latter as the next subsection indicates.

\section{Part-Time Workers}

It is ironic that the enforcement of the EEOL-which was to protect the interests of female workers - coincided with the appearance and then the rapid increase of 
part-time workers who were predominantly female (81 percent in 1995). In 1986, female part-workers were 24 percent of female regular employees; in 1995, the percentage had increased to 29 percent. This increase means that two-thirds of the rise in female employment from 1986 to 1995 can be accounted for by the increase of part-time workers. These part-time workers are most numerous in wholesale and retail trade and eating establishments, roughly equal in number to female regular employees. Female part-time employees also are found in the service, real estate, and manufacturing sectors.

The reason that employers hire part-time workers is that they are much cheaper to employ and easier to hire and fire. Their average hourly earnings were about $¥ 800$ in 1992 when female regular employees were paid about $¥ 1500$ per hour. In addition, employers do not pay fringe benefits and bonuses to part-time workers. During the late 1980s, female part-time workers increased in number by 11 percent per annum while female regular workers increased by only 3.5 percent per annum. However, in 1993, the number of female part-time workers declined by 9 percent while the number of female regular workers increased by 1.8 percent.

When most of the increase in female employment is part-timers, the increase in the female LFPR is definitely not a matter for rejoicing. Working conditions are becoming worse as female employment grows. This outcome is not what the EEOL is supposed to produce.

\section{Foreign Workers}

Japan was closed off from the rest of the world for 215 years (1639-1853) except for intermittent trade with Holland, China, and Korea. Though the country was opened in 1853, foreign immigrants residing in Japan continued to be few in number except for Koreans who migrated to Japan after Korea was annexed in 1910. The limited direct contact with foreigners helped Japan to retain its strong sense of xenophobia, which, in turn, contributed to Japan's "pure blood" policy. Its geographical location and language difficulty also precluded Japan from the flow of migratory foreign workers which expanded in the postwar world.

Thus, the arrival en masse of foreign workers to Japan in the late 1980s was a shock to the Japanese. What happened was that migratory workers from poor Asian countries had been cut off from their usual places of work because of the worldwide economic slowdown. They had to look for work elsewhere and found Japan to be a very promising place. To them, even meager wages for menial jobs seemed to be attractive enough to offset the high transportation costs.

The menial jobs were crying for employees because the well-educated Japanese workers looked askance at such jobs. Most Japanese people refused to accept these jobs unless they were older workers desperate enough to seek them. Thus there was a pent-up demand for low-class jobs, and employers were willing to accept any warm bodies to fill them. The incoming supply of unskilled foreign 
workers filled this bill nicely. These jobs included, among others, construction hard hats for males, bar hostesses for females, and restaurant attendants for both sexes. That is, these are jobs which Japanese workers regarded as $3 \mathrm{~K}$ - kitsui (tough), kitanai (dirty), and kiken (risky).

Foreign workers arrive in Japan on a nonwork visa which allows them to stay for only a short time, but they seek employment illegally and overstay. According to the Ministry of Justice, the number of such illegal aliens rose from 28,000 in 1986 to 100,000 in 1989 and then to 299,000 in 1993 . The number has been somewhat lower since then because of the depressed job market in Japan. ${ }^{10}$

Though the number of illegal aliens is still 0.5 percent of Japan's labor force, the increase is highly noticeable in pure-blood Japan because foreign workers tend to form their ghettos in large cities such as Tokyo. Many unsavory crimes are attributed to these groups of people. Despite the increased influx of foreign workers, the Japanese government has not changed its tough immigration law. It still permits a long-term visa to be granted only to those who are regarded as highly qualified.

However, the trend for internationalization in the human area seems to be inevitable in this increasingly global world economy. One consequence of increased contact with foreigners is an escalation in the number of international marriages. The latest statistics show that nearly 4 percent of new marriages in

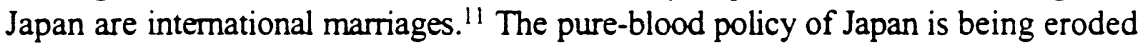
in a slow but steady manner.

\section{Unions and Shunto}

The Occupation policy encouraged workers to organize themselves. The unionization ratio reached 56 percent in 1949 - the postwar peak. By 1954, however, the ratio had declined to 35 percent, the level it stayed at until 1970 . Then, the ratio started to decline again: 31 percent in 1980 and 25 percent in 1990. The latest information in 1995 shows a level of 23.8 percent. The ratio declined not because union membership fell, but because unions are concentrated in nongrowth industries such as manufacturing. In fact, membership has remained flat, with new workers going into the tertiary sector which is largely nonunionized.

Unions are strong in manufacturing, finance, transportation, public utilities, and government. Large companies are unionized, and base wages are annually determined by collective bargaining in the first quarter of the year before the new business year begins in April. This Shunto (Spring Offensive) determines the annual rate of across-the-board wage increases ("baseup"). When union agreements are concluded, nonunion firms follow suit. Though the unionization ratio has been falling, the Shunto has been considered an important annual ritual ever since it started in 1955.

However, the depressed economy of the early 1990s put union power in 
jeopardy. The Shunto rate of wage increase is known to fluctuate, with a short time lag, according to prevailing macroeconomic conditions. The next year's wage increases tend to be lower when the economy is in a recession. In recent years, the peak wage increase in the Shunto negotiations was 5.9 percent in 1990. From then on the rate of increase continued to fall until it reached 2.8 percent in 1995. The rate was only slightly higher in 1996. Thus, it is widely believed that unions have outlived their usefulness, and that the Shunto mode of wage negotiations is outmoded.

\section{The Business System}

One member of the triad is big business, which can be identified with the six keiretsu groups of Japan. ${ }^{12}$ The dominance of the keiretsu groups over Japan's business sector is too well known to need any detailed explanation. Our interest here is in determining how the keiretsu groups as a whole have adapted themselves to macroeconomic changes in the Japanese economy.

A keiretsu group consists of firms which are members of the group's presidents' club. While the number of firms varies from group to group, the average is thirty-two per group. Member firms are divided broadly into banking/insurance and nonfinancial. On average, one group has four financial institutions-one city bank, one trust bank, one life insurance company, and one marine and fire insurance company. ${ }^{13}$ Of twenty-eight nonfinancial firms per group, nineteen are manufacturing firms. ${ }^{14}$

Let us first see how the six keiretsu groups as a whole divide their activities between their banking and insurance and their nonfinancial activities (see Table 5A). In terms of employment, the keiretsu are about 85-90 percent in the nonfinancial sector. However, in terms of total assets, there is a large difference. In 1970, the keiretsu divided their business equally between the two fields, but by the early 1990s, the division had changed to three to one. To begin with, the banking and insurance sector is highly capital-intensive and has become even more so over time (Table 5B).

The above is an internal change within the keiretsu groups. Next, we will look at how the keiretsu's relative importance has changed within their respective industries (see Table 6). The industry total shown for banking and insurance firms is the sum total of the total assets (book value) of all banks and insurance companies. The industry total shown for nonfinancial firms is the total assets (book value) of all nonfinancial corporations as reported in the Ministry of Finance's Corporate Enterprise Statistics.

Table 6 shows that, in the nonfinancial field, keiretsu's share fell from 24 percent in 1970 to 11.2 percent in 1995. In contrast, for banking and insurance, the keiretsu's share rose from around 40 percent in 1970 to above 50 percent in the late 1980s. This result means that the keiretsu groups have shifted their resources from nonfinancial to financial for more than respective industries have 
Table 5

The Six Keiretsu Groups

(A) Banking and Insurance/as Percent of Group Total

1970

1975

1980

1985

1990

1995

1970

1975

1980

1985

1990

1995

\begin{tabular}{cc} 
Employment & Total assets \\
\hline 8.5 & 49.4 \\
10.2 & 53.5 \\
11.8 & 61.1 \\
11.3 & 70.4 \\
14.3 & 77.3 \\
15.0 & 77.1
\end{tabular}

(B) Total Assets/Employment ( $¥$ mn per person)

(1) Financial

13.59

35.31

62.70

122.96

227.19

213.76
(2) Nonfinancial

$(1) /(2)$

$\begin{array}{rr}1.84 & 7.4 \\ 3.44 & 10.3 \\ 5.19 & 15.9 \\ 6.57 & 18.7 \\ 11.10 & 20.50 \\ 11.20 & 19.10\end{array}$

Source: Toyo Keizai, Kigyo keiretsu soran.

done. This is clearly seen in Table 7, which compares the quinquennial growth rates of total assets (book value) between keiretsu and industry totals.

The financial sector has been the rising star of the Japanese economy in the slow growth period. The nonfinancial sector has lost its erstwhile luster as the engine of Japan's economic growth. In response to this macroeconomic change, the keiretsu groups have adapted themselves by shifting the center of their business activities from the nonfinancial areas to the financial sphere, namely, from production to services. This adaptation reveals the ability of Japan's big businesses to survive.

This ability to adapt has been demonstrated time and again in Japan's business history. Late in the prewar period-at the time when Japan started to develop heavy industry - it was zaibatsu which poured resources into capital-intensive heavy industry. The keiretsu, the successor to the zaibatsu, rebuilt the production sector of the war-torn Japanese economy. The rapid growth period was the keiretsu's heyday for industrial growth. Now in the slow growth period as financial deepening proceeds at a rapid rate, the keiretsu groups are increasingly moving into the financial area.

This, however, does not mean that the keiretsu groups have stopped improving themselves in the nonfinancial field. As shown in Table 8, while their market shares 
Table 6

Total Assets (Book Value): Keiretsu/Industry (in percent)

\begin{tabular}{lll} 
& B\&I & NFC \\
\cline { 2 - 3 } 1970 & 41.5 & 24.0 \\
1975 & 40.9 & 20.9 \\
1980 & 41.9 & 16.8 \\
1985 & 53.8 & 15.6 \\
1990 & 57.3 & 14.8 \\
1995 & 52.40 & 11.20
\end{tabular}

Source: Toyo Keizai, Kigyo Keiretsu Soran.

Note: Industry totals are: $\mathrm{B} \& \mathrm{I}=$ all banks and insurance, from BOJ, ESA, 1996, Tables 13, 30 , and $31 ;$ NFC $=$ Ministry of Finance, Hojin kigyo tokei [Corporate Enterprise Statistics].

Table 7

The Growth Rates of Total Assets (Book Value) (in percent)

\begin{tabular}{|c|c|c|c|c|c|c|}
\hline & \multicolumn{3}{|c|}{ Keiretsu } & \multicolumn{3}{|c|}{ Industry total } \\
\hline & $T$ & $F$ & NF & $T$ & $F$ & NF \\
\hline $1970-75$ & 15.3 & 17.9 & 12.6 & 17.3 & 18.3 & 16.7 \\
\hline $1975-80$ & 8.5 & 22.0 & 5.4 & 9.7 & 10.5 & 9.3 \\
\hline $1980-85$ & 12.3 & 16.0 & 5.6 & 8.3 & 10.3 & 7.1 \\
\hline $1985-90$ & 13.3 & 14.9 & 9.0 & 11.6 & 13.4 & 10.2 \\
\hline $1990-95$ & -0.8 & -0.9 & -0.6 & 0.8 & 0.5 & 3.3 \\
\hline $1970-90$ & 12.3 & 14.9 & 8.1 & 11.7 & 13.1 & 10.8 \\
\hline
\end{tabular}

Source: Table 6.

Note: $\mathrm{T}$ : the sum of $\mathrm{F}$ and NF, F: banking and insurance, NF: nonfinancial.

have been falling, the keiretsu/non-keiretsu differentials have been rising in sales per worker and total assets per worker (except in the early 1990s). Roughly speaking, the keiretsu firms are four times as productive and capital-intensive as smaller non-keiretsu firms. It is these keiretsu production firms that compete in the international market.

\section{The Government System}

From November 1955 when the Liberal Party and the Democratic Party merged to form the Liberal Democratic Party (LDP) to July 1993 when the LDP lost the majority in the general election of the House of Representatives, the LDP contin- 
Table 8

Shares of the Keiretsu Groups in the Nonfinancial Corporate Sector (in percent)

\begin{tabular}{|c|c|c|c|c|c|c|}
\hline & $\begin{array}{l}\text { Sales } \\
\text { (S) }\end{array}$ & $\begin{array}{l}\text { Employment } \\
\text { (N) }\end{array}$ & $\begin{array}{c}\text { Total assets } \\
\text { (A) }\end{array}$ & $\begin{array}{l}\text { Keiretsu/A } \\
\text { (multiple) } \\
\mathrm{S} / \mathbb{N}\end{array}$ & $\begin{array}{l}11 \text { NFCs } \\
\text { ANN }\end{array}$ & $S / A$ \\
\hline 1970 & 19.3 & 8.2 & 24.0 & 2.7 & 3.2 & 0.8 \\
\hline 1975 & 18.2 & 7.4 & 20.9 & 2.8 & 3.1 & 0.9 \\
\hline 1980 & 17.1 & 5.8 & 16.8 & 3.4 & 3.3 & 1.0 \\
\hline 1985 & 17.6 & 5.3 & 15.6 & 3.8 & 3.3 & 1.2 \\
\hline 1990 & 14.8 & 3.9 & 14.8 & 4.3 & 3.9 & 1.1 \\
\hline 1995 & 12.6 & 3.6 & 11.2 & 3.5 & 3.2 & 1.1 \\
\hline
\end{tabular}

Sources: Toyo Keizai, Kigyo keiretsu soran; nonfinancial total from Ministry of Finance, Hojin kigyo tokei.

ued to be Japan's ruling party; that is, the LDP ruled Japan for thirty-eight years. Even though there were many other parties - the largest of which was the Japan Socialist Party (JSP)-Japan was a de facto one-party country for a very long period of time. The LDP oversaw Japan's economic recovery and rapid growth, and the economic policy which the LDP pursued was instrumental in promoting that growth.

Though it is a conservative, pro-business party, the LDP is not a single party unified along a well-articulated political ideology. Rather, it is a party of several factions, each of which is led by a powerful leader who has the ability to collect funds from the public, particularly from the business sector. None of these factions claims majority in the party. Thus, a couple of the factions usually agreed to cooperate in electing one of the competing leaders to the party's presidency, who, in turn, automatically assumes premiership.

This arrangement, which continued for the full thirty-eight-year period, did not lead to political stability. During this time the LDP appointed fifteen presidents-cum-prime ministers. There were only four presidents who served for more than three years (the normal tenure of presidency): Nobusuke Kishi (three years, three months, February 1957-June 1960), Hayato Ikeda (four years, four months, July 1960-October 1964), Eisaku Sato (seven years, eight months, November 1964-June 1972), and Yasuhiro Nakasone (five years, six months, November 1982-October 1987). The first three ruled Japan consecutively through the rapid growth period. In other words, the rapid growth period was also a period of political stability-rare in Japan. ${ }^{15}$

Between Sato and Nakasone, there were five ministers in ten years. The first of them, Kakuei Tanaka (two years, five months July 1972-November 1974) had 
to resign because he was indicted for his involvement in the Lockheed Scandal. He was later found guilty of having accepted a large bribe, but he died of a long illness before he went to prison.

The presidency did not take a turn for the better after Nakasone. Noboru Takeshita, his successor (one year, seven months November 1987-May 1989) was forced to resign before his tenure was over because of another economic scandal. The last phase of the LDP rule witnessed four prime ministers in less than six years, during which time the LDP was plagued by successive revelations of economic scandals.

Finally, in the July 1993 general election, the LDP lost the majority of the Lower House - not because it became less popular but because a sizeable segment of the party seceded from the party. However, it was the economic scandals that rocked the foundation of the LDP and eventually splintered it. ${ }^{16}$

By its nature, politics is prone to be a dirty business. Diet members face reelection every four years or less, and winning elections is expensive. Politicians must solicit election funds from private sources, especially from big businesses. In turn, the big businesses make large political contributions because they expect to be repaid later with special favors granted by the politicians they support. The more regulated the industrial sector in which a big business is involved, the greater the payback for its political contributions. ${ }^{17}$

Gift giving is a common social practice with a long history in Japan. In the final analysis, all gifts are self-serving. Gifts must be a form of bribes even if they are given strictly on good will. Likewise, it is difficult to distinguish between bona fide political contributions and bribes since, either way, the contributors expect some kind of repayment later. Because of the extensive practice of gift exchanges, the Japanese tend to be insensitive and indifferent to the whole affair. In this general climate, political corruption becomes an everyday affair.

As long as the contributions or gifts remained hidden from the general public, people remained complacent and politicians were safe from public scrutiny. However, this all changed in the late 1980s - the boils burst open and politics was forced to clean its dirty linen.

Then, how clean or how corrupt is Japanese politics at present? Though it covers more than politics, a recent international comparison of forty-one countries by a think tank concerning corruption shows that Japan stands exactly in the middle. ${ }^{18}$ Generally speaking, the more economically developed a country is, the less corrupt it tends to be. Thus, most countries above Japan are developed countries and most below Japan are developing countries.

The observed correlation between the stage of economic development and political cleanliness hinges critically on how concentrated political power is in a country. In developing countries in which the masses are illiterate, governance falls in the hands of a few elite who, in turn, are supported by big business and the military. Bureaucracy is strong in these countries; if one wishes to have anything done quickly, one must bribe the proper authorities. As countries 
develop, they become more democratic because the masses demand political participation. Political power tends to be deconcentrated, and therefore corruption declines.

Japan stands much lower in this scheme of international rankings than it should based on its stage of economic development. Obviously it is still controlled by the few, namely, the triad. It can be said that Japan is economically well developed but politically underdeveloped. An important corollary follows: If Japan wishes to reform itself, it has to begin by cleaning up its politics.

\section{Deregulation}

One means by which politicians and bureaucrats exercise their power is administrative regulations, and Japan is alleged to be a country burdened with administrative regulations. This is almost tautological with the top-down nature of Japan's method of governing. Without regulations, the government finds it hard to rule effectively.

However, regulations tend to proliferate. It is in this light that the national government started to reduce the number of regulations. It appointed a succession of Administrative Reform Councils starting in the early 1980s. ${ }^{19}$ After its tenure of three years, each council submitted its recommendations to the prime minister. In addition to the official council, Prime Minister Hosokawa (who succeeded the LDP government in August 1993) created a special private commission to prepare a set of recommendations for deregulation. ${ }^{20}$

Needless to say, Japan continued to be regulated heavily by the goverment in the prewar period, but 1940 is singled out as the year that brought government regulations to a higher level. To mobilize resources for wartme, the National Mobilization Law was adopted in 1938. A new Economic System was declared in 1940. Noguchi (1955) calls it the 1940 system and argues that it is the 1940 system that has survived into postwar Japan.

Regulations were a vital element of the 1940 system. They made economic ministries powerful during the war. Because of the shortages during the immediate postwar years, the Postwar Reform even strengthened their control power since strict administrative guidance was needed for resource allocation. The food supply had to be controlled by the Ministry of Agriculture, funds had to be supplied by the Bank of Japan, foreign exchanges by the Ministry of Finance, and import restrictions by the MITI, to cite just a few. All these controls needed regulations, and they stayed in place through the rapid growth period because the resource supply was less than the resource demand. Resources had to be rationed by the intervention of the government in the free market mechanism.

This supply-and-demand imbalance disappeared as the economy slid into slow growth. However, regulations survived even though their usefulness was over. Those in power disliked any change in the status quo because that meant the loss of their vested power. Despite their resistance, the market insisted that 
these regulations be removed for its own sake. The demand for deregulation arose from this market force. How the Japanese government will continue to respond to this demand is yet to be confirmed. ${ }^{21}$

\section{Macroeconomic Changes}

\section{The Labor Market}

Population Aging

Population aging - a phenomenon common to all countries-is a problem which impacts with inordinate intensity on both the supply and demand sides of the Japanese economy. What makes Japan's case unique is its rapid speed at which its population aged. The Japanese used to die young with a life expectancy not much above forty years in the 1930s. After World War II life expectancy started to rise steadily. By 1994 it was 83.0 years for females and 76.6 years for malesthe highest in the world.

The other side of a longer life expectancy is a steadily increasing older population. As a percent of the total population, people aged sixty-five and over rose from 5.7 percent in 1960 to 14.1 percent in 1995. Its future level is given in Table 9 based on the January 1997 Ministry of Welfare's population projection. ${ }^{22}$

The labor force, 44 years and younger, saw its share falling from 1970 on.

Table 9 shows a significant change in the age structure of the labor force. Its median age has been steadily rising over time since 1970, and the trend of the labor force becoming older will continue. As we noted, the emerging age structure will be incompatible with the maintenance of the lifetime employment system as we know it.

However, there are other economy-wide impacts. One is on the household savings rate. The continued increase in population aging means more households which contain retired persons. If one accepts the life-cycle saving hypothesis, retired households dissave to support themselves in retirement. That is, negative savings will increase while positive savings will decrease among these households. The net effect will be a decline in the average household savings rate.

However, the actual record shows that, so far, the decline in the average savings rate has been relatively modest. (In fact, the household saving rate remained at 13 percent from 1988 to 1995 (EPA, $A R N A$, 1997). If anything, the observed decline in the average household savings rate can be explained by the narrowing of the wealth gap, namely, the gap between the target level of accumulation and the actual level of accumulation (Sato 1995d). The target level itself has remained stable thus far in relation to household disposable income.

Further, Japan's older households are not decumulating their assets as the naive version of the life-cycle savings hypothesis claims. It is true that those older households who are at the poverty line because their spendable incomes are mostly from pension benefits do not save. However, about 38 percent of males 
Table 9

The Labor Force by Age

\begin{tabular}{|c|c|c|c|c|c|c|c|c|c|c|c|c|c|}
\hline Age & 1960 & 1965 & 1970 & 1975 & 1980 & 1985 & 1990 & 1995 & 2000 & 2005 & 2010 & 2020 & $\begin{array}{l}\text { U.S. } \\
1995\end{array}$ \\
\hline LFPR & 69.2 & 65.7 & 65.4 & 63.0 & 63.3 & 63.0 & 63.3 & 63.4 & 63.3 & 62.5 & 63.2 & 61.9 & 66.6 \\
\hline $\begin{array}{l}\text { Over } 65 / \text { Total pop. } \\
\text { Females/Labor force }\end{array}$ & $\begin{array}{r}5.7 \\
40.7\end{array}$ & $\begin{array}{r}6.3 \\
39.8\end{array}$ & $\begin{array}{r}7.1 \\
39.3\end{array}$ & $\begin{array}{r}7.9 \\
37.9\end{array}$ & $\begin{array}{r}9.1 \\
38.7\end{array}$ & $\begin{array}{l}10.3 \\
39.7\end{array}$ & $\begin{array}{l}12.1 \\
40.6\end{array}$ & $\begin{array}{l}14.6 \\
40.5\end{array}$ & $\begin{array}{l}17.8 \\
41.5\end{array}$ & $\begin{array}{l}19.6 \\
42.2\end{array}$ & $\begin{array}{l}22.0 \\
43.5\end{array}$ & $\begin{array}{l}26.9 \\
44.4\end{array}$ & $\begin{array}{l}12.7 \\
46.0\end{array}$ \\
\hline $\begin{array}{l}\text { Growth rate } \\
\text { Labor force } \\
\text { Population }\end{array}$ & & & & & $\begin{array}{l}1.2 \\
1.1\end{array}$ & & & & & & & & $\begin{array}{l}1.0^{2} \\
1.0^{2}\end{array}$ \\
\hline
\end{tabular}

Sources:

Labor force: Prime Minister's Office, Labor Force Survey, population: Census of Population.

United States: SABUS, 1996, Tables 16, 24, 614, and 615.

Projections: Population, due to the Ministry of Welfare (January 1997, medium version); labor force, obtained by population $\times$ LFPR, where LFPRs of males, 15-64 and over 65 and females over 65 are assumed to remain unchanged from the 1993 levels and the LFPR of females, $15-64$ is assumed to increase by 2.2 percentage points per five years (the trend increment between 1975-93).

Notes:

1. Ages $16-19$.
2. $1990-95$ (Population is projected to grow at 0.8 percent per annum from 1995 to 2025 ). 
aged sixty-five and over are still in the labor force, and they earn more than they spend. Thus they tend to have a relatively high savings rate. When rich and poor older households are taken together, their average savings rate is quite comparable with that of younger households. This means that population aging does not automatically translate into a decline in the household savings rate - provided that a member of the older household continue to work at the present rate.

There is, however, at least one negative factor in this scenario. The increase in the older population will force the national government to cut back on social security and health benefits to older households. The decline in public support must be offset by an increase in private support, either by the older generation themselves out of their accumulated savings or by their children who then have to reduce their own rate of savings. Either way, private saving will be reduced.

\section{The Labor Force Participation Ratio and the Unemployment Ratio}

The labor force participation ratio (LFPR) does not remain constant. For male workers aged fifteen to sixty-four the LFPR declined slightly from 85.2 percent in 1975 to 82.8 percent in 1990. For males, sixty-five and over, the LFPR continued to decline until 1985 but it has stayed at 37-38 percent through the present. For female workers aged fifteen to sixty-four the LFPR continued to rise from 49.6 percent in 1975 to 57.0 percent in 1990. For females, sixty-five and over, the LFPR has remained stable at around 15-16 percent since 1975.

As we have already explained, the LFPRs temporarily deviate from their long-term trends when the labor market is depressed, as in the early 1990s. As a result, the unemployment rate does not accurately reflect the state of the labor market. A more reliable indicator of the prevailing condition in the labor market is the ratio of job offers to job applications at the government-run job exchange, which is referred to as the vacancy ratio below.

The vacancy ratio of 1 may be taken as a sort of labor-market equilibrium. The vacancy ratio was above 1 in 1967-74, peaking at 1.76 in 1973. Then the labor market collapsed and it fluctuated around 0.6 between 1975 and 1987. It rose above 1 again in 1988-92, peaking at 1.40 in 1990-91. Since then, the vacancy ratio has remained at slightly over 0.6 (0.67 in 1996).

\section{Working Hours}

A significant contribution of the Postwar Reform was a reduction in the number of working hours. In the prewar period, a twelve-hour workday was common. Though the number of hours per day was cut substantially, monthly hours still totaled as high as 200 hours in the early postwar years (Table 10). However, when the slow growth period started, hours declined to around 175 hours per month or 2,100 hours per year.

This yearly total was still very high when compared with other advanced countries. Therefore, a reduction in the number of working hours became a press- 
Table 10

Monthly Hours of Work, Regular Workers, and Establishments with Thirty or More Employees

\begin{tabular}{|c|c|c|c|c|c|c|}
\hline \multirow{2}{*}{$\frac{\text { Sector }}{\text { Year }}$} & \multicolumn{3}{|c|}{ Total } & \multicolumn{3}{|c|}{ Nonscheduled } \\
\hline & $\|+\| 1$ & 11 & III & $I I+I I I$ & II & III \\
\hline 1955 & 194.8 & 197.1 & 192.1 & 16.5 & 17.3 & 15.6 \\
\hline 1960 & 202.7 & 207.6 & 195.6 & 21.9 & 24.7 & 17.8 \\
\hline 1965 & 192.9 & 194.6 & 190.4 & 16.5 & 17.5 & 15.1 \\
\hline 1970 & 187.7 & 189.9 & 184.5 & 17.8 & 19.6 & 15.2 \\
\hline 1970 & 186.6 & 189.9 & 183.5 & 16.7 & 19.6 & 13.9 \\
\hline 1975 & 172.0 & 172.7 & 171.4 & 10.7 & 10.4 & 10.8 \\
\hline 1980 & 175.7 & 181.1 & 171.4 & 13.5 & 16.0 & 11.5 \\
\hline 1985 & 175.8 & 181.8 & 171.5 & 14.8 & 17.6 & 12.8 \\
\hline 1990 & 171.0 & 179.9 & 164.7 & 15.5 & 18.7 & 13.2 \\
\hline 1995 & 159.1 & 166.3 & 154.1 & 12.6 & 13.7 & 11.8 \\
\hline
\end{tabular}

\begin{tabular}{lrrr}
\multicolumn{5}{c}{$g(H)$ (in percent) } \\
\hline $1955-60$ & 0.8 & 1.0 & 0.4 \\
$1960-65$ & -1.0 & -1.2 & -0.5 \\
$1965-70$ & -0.4 & -0.5 & -0.6 \\
$1970-75$ & -1.6 & -1.9 & -1.4 \\
$1975-80$ & 0.4 & 1.0 & 0.0 \\
$1980-85$ & 0.0 & 0.1 & 0.0 \\
$1985-90$ & -0.6 & -0.2 & -0.8 \\
$1990-95$ & -1.4 & -1.6 & -1.3
\end{tabular}

Sources: Ministry of Labor, Monthly Labor Statistics; industries are weighted by persons engaged, reported in EPA, $A R N A$.

Note: II+III and III are exclusive of services for 1955-70 and inclusive of services for 1970-95.

ing political issue. The 1992 national economic plan, which advocated "Better Quality of Life," proposed a target of 1,800 working hours per year. Unwittingly, the depressed economy of the early 1990s helped the government achieve this goal. Monthly hours fell to 152.7 hours per month or 1,900 hours per year by 1994.

Will the number of working hours rise once again if the Japanese economy is revived? The Labor Standards Law reduced the work week from forty-four hours to forty hours as of April 1994. However, firms with less than 300 workers were exempted from this law until March 1997. As of now, only 37 percent of firms with less than ten workers enforce the forty-hour week, and there is strong 
resistance to enforcing the law on schedule. Nonetheless, the trend is for less working hours.

\section{Paid Holidays}

Another well-known feature in Japan's labor economics is a reluctance of workers to take paid holidays. Workers were authorized to take up to 14.4 days in paid holidays in 1980 and 17.2 days in 1995, but the number of actual days taken was 8.8 days in 1980 and 9.5 days in 1995. Though a few large Japanese firms started to force their employees to take one week off by closing their offices and factories in the summer, apparently Japanese workers are still unwilling to exercise their legal right in this regard. ${ }^{23}$

\section{Technical Change and the Industrial Structure}

Needless to say, technical change is the most vital factor in economic growth. A country's productivity is increased in three ways: (a) by technological innovations introduced in individual industries, (b) by increases in capital intensity, and (c) by transfers of resources from low-productivity industries (agriculture) to high-productivity industries (modern manufacturing). All three occur simultaneously in the process of strong economic growth. This is why overall productivity growth was particularly high in the rapid growth period, especially in the late 1960s.

We quantify technical change by the rates of labor productivity growth. ${ }^{24}$ Excluding the public sector, ${ }^{25}$ private industry is divided into three sectors: primary (I) is agriculture, forestry, and fisheries + mining; secondary (II) is manufacturing + construction + electricity, gas, and water, and tertiary (III) is all the rest. Output $(Y)$ is measured by the GDP produced in each sector in constant prices. Labor is measured by the number of persons engaged in production $(N) .{ }^{26}$ The growth rate of labor productivity $(Y / N)$ has been measured every five years since 1955 (see Table 11). ${ }^{27}$

Productivity growth was high before 1970 . Growth of the overall output was accentuated between 1955 and 1970 because of a massive reallocation of resources from the primary sector to the secondary and tertiary sectors. Productivity growth was low in the early 1980s when the economy was generally depressed. This was the period in which Japan's "hollowization" (küdōka) was frequently discussed. Again, productivity growth declined sharply in the early 1990 s, even to negative levels for the secondary sector. ${ }^{28}$ It is clear that the demand side and the supply side interact in the growth process. When demand is high, productivity growth is stimulated and resources are transferred from agriculture to industry. When demand is depressed, productivity growth also declines and resource transfers stop.

As the economy develops, the pnmary sector shrinks and resources are 
Table 11

Labor Productivity Growth and the Employment Structure in Private Industry

(A) Labor productivity growth ( $g(Y / N)$, in percent)

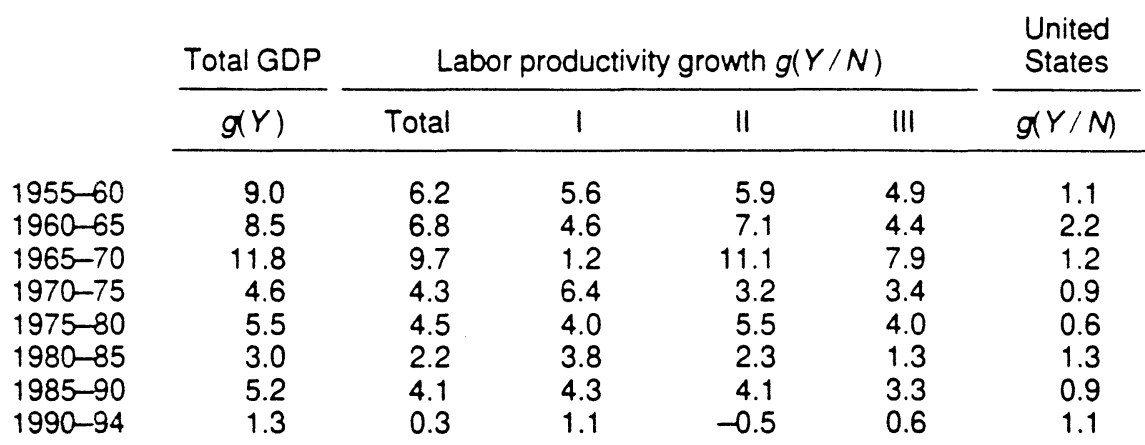

(B) The employment structure (in percent)

\begin{tabular}{lrrrr} 
& Total & \multicolumn{1}{c}{ I } & II & III \\
\cline { 2 - 5 } 1955 & 100.0 & 45.0 & 25.6 & 29.3 \\
1965 & 100.0 & 27.8 & 36.8 & 35.6 \\
1975 & 100.0 & 17.1 & 38.6 & 44.3 \\
1985 & 100.0 & 12.1 & 37.0 & 50.9 \\
1994 & 100.0 & 8.2 & 37.5 & 54.3 \\
& & & & \\
U.S. & & & & \\
1970 & 100.0 & 6.4 & 34.4 & 59.2 \\
1992 & 100.0 & 3.7 & 25.5 & 70.8
\end{tabular}

Sources:

(A) Japan: EPA, $A R N A$; United States: ERP, February 1996, Table B-2 and B-31.

(B) Japan: EPA, ARNA; United States: OECD, National Accounts.

poured into the secondary and tertiary sectors. However, at some point in time, manufacturing (secondary) becomes saturated and employment stops growing in that sector. In Japan, this point was reached in 1973. Since that time the employment share for the secondary sector has remained stable. The continued contraction of the primary sector has been matched by a corresponding expansion of the tertiary sector. Japan's Service Revolution is identified with this turnaround. In the following "Quo Vadis" section, we shall examine how Japan's employment structure will change henceforth.

The information in Table 11 reveals an interesting feature: Labor productivity growth fluctuated in the same direction among the sectors with one significant exception-the primary sector from 1965 to 1970. We relate 
Table 12

Productivity Growth Regressions

\begin{tabular}{cccc}
\multicolumn{4}{c}{$g\left(Y_{i} / N_{i}\right)=d i g(Y / N)+d_{i 0}$ (in percent) } \\
$i$ & $d_{i}$ & $d_{i 0}$ & $R^{2}$ \\
\hline I & 0.57 & 2.0 & 0.572 \\
II & $(0.22)$ & $(2.2)$ & \\
& 1.18 & -0.8 & 0.964 \\
III & $(0.09)$ & $(1.2)$ & \\
& 0.77 & 1.1 & 0.958 \\
& $(0.07)$ & $(0.09)$ &
\end{tabular}

Note: Sector I calculation excludes 1965-70.

$g\left(Y_{i} / N_{i}\right)$ to $g(Y / N)$ with the result reported in Table $12 .{ }^{29}$ This table shows a well-known fact: That productivity growth is above average in the secondary sector and below average in the primary and tertiary sectors. The closest relation is between the secondary and the tertiary sectors, as is verified by the following regression:

$$
g\left(Y_{3} / N_{3}\right)=0.63 g\left(Y_{2} / N_{2}\right)+0.27(\%), R^{2}=0.988
$$

Equation 1

According to equation (1), we have:

$$
0.72 \% \lesseqgtr g\left(Y_{3} / N_{3}\right) \lesseqgtr g\left(Y_{2} / N_{2}\right)
$$

According to this inequality, productivity growth was higher in the tertiary sector than in the secondary sector during 1990-94. Normally, productivity growth in the tertiary sector is about two-thirds of that in the secondary sector. In every country productivity growth tends to be lower in the tertiary than in the secondary sector. In the case of Japan, there is an additional feature that the productivity level is absolutely lower in the tertiary sector than in the secondary, and the difference between them is very sizable.

This feature becomes apparent when we compare the tradable PPP (purchasing power parity) and the nontradable PPP between Japan and the United States. We may assume that the tradable PPP can be approximated by the exchange rate of $¥ 110 / \$$ (September 1996). ${ }^{30}$ The overall PPP for 1994 was $¥ 155 / \$$ (private consumption) between Tokyo and New York City (EPA) and $¥ 177 / \$$ (GDP) between Japan and the United States (OECD). ${ }^{31}$ When corrected for price changes, the 1995 PPP was estimated to be $¥ 150 / \$$ (EPA) and $¥ 174 / \$$ (OECD). For the former, we note that the cost of living is higher by 12 percent in Tokyo and by 
60 percent in New York City relative to the national average. ${ }^{32}$ Then the PPP (private consumption) is raised from $¥ 150 / \$$ to $¥ 214 / \$$. The overall PPP for 1995 amounts to $¥ 174 / \$$ (OECD) and $¥ 214 / \$$ (EPA). The nontradable PPP then is estimated to be $¥ 181 / \$-¥ 226 / \${ }^{33}$

Thus, nontradables are 65 percent to 105 percent more expensive than tradables when Japan is compared with the United States. Nontradables are more expensive in Japan for various reasons such as: (a) services are produced inefficiently by small firms (especially in retail trade); (b) many service prices are publicly regulated (including public utilities, postal and telephone rates, train fares, taxi fares, and so on); (c) markets for services are imperfectly competitive; and (d) results of restricting free entry into the regulated industries. Existing suppliers have less incentives to improve productivity because of the heavy protection. Thus, postal rates are 2.6 times and train fares are 1.7 times higher in Japan than in the United States. ${ }^{34}$ Why can't these rates be reduced to the international level?

\section{The Balance-of-Payments}

One salient feature of Japan's balance-of-payments is that it has been continuously in a surplus since the mid-1960s except for a few oil shock years. The current-account surplus adds to the net accumulation of foreign assets. Japan has been the largest net creditor to the world since the late 1980s when the United States switched from the world's largest net creditor to the largest net debtor. As foreign assets eam investment income, the balance-of-payments now has a builtin mechanism to remain in a surplus. Even though the Japanese yen has been much stronger since the G5 Plaza Accord of September 1985, a surplus has continued in Japan's balance-of-payments.

The main part of the current-account surplus, however, is the trade surplus of merchandise. Japan has a net deficit in the service trade because Japan depends more on foreign shipping than on domestic shipping. Merchandise trade (f.o.b.) as a percent of the GDP is shown in Table 13 for 1985-95. The trade surplus has been on the positive side for the entire period. There is a rule of thumb that Japan's trade surplus tends to rise in a recession year because exporters engage in an export drive to promote sales overseas. Accordingly, the trade surplus peaked in 1986-87 (1986 was a recession year), and then fell in 1988-90 when the Japanese economy was in a boom. Then, once again, the trade surplus rose from 1991 to the present.

The performance of merchandise exports and imports is also influenced by the export and import prices relative to the domestic prices. The relative prices are also affected by the position of the exchange rate relative to the PPP. The yen-dollar rate has been in a downward trend ever since the September 1985 Plaza Accord. The export price index relative to the domestic price index has also been in a downward trend (particularly in the early 1990s), reflecting the faster rate of technical change in large (exported-oriented) firms than in small 
Table 13

Merchandise Trade, 1985-95 (in percent)

\begin{tabular}{rrrrrrr} 
& $X / Y$ & $M / Y$ & $N X / Y$ & $P_{X} / P$ & $P_{M} / P$ & $e(¥ / \$)$ \\
\cline { 2 - 7 } 1985 & 13.0 & 9.0 & 4.0 & 124.6 & 155.5 & 238.1 \\
1986 & 10.3 & 5.8 & 4.5 & 104.4 & 98.4 & 163.0 \\
1987 & 8.7 & 5.3 & 4.5 & 98.1 & 90.7 & 144.5 \\
1988 & 8.9 & 5.7 & 3.4 & 93.8 & 84.4 & 128.2 \\
1989 & 9.3 & 6.7 & 2.6 & 98.3 & 92.5 & 138.1 \\
1990 & 10.2 & 7.3 & 2.9 & 100.0 & 100.0 & 144.9 \\
1991 & 10.2 & 6.0 & 4.2 & 97.1 & 88.2 & 134.6 \\
1992 & 10.0 & 5.4 & 4.6 & 95.5 & 80.7 & 136.6 \\
1993 & 9.3 & 4.9 & 4.4 & 90.2 & 64.5 & 111.1 \\
1994 & 9.3 & 5.1 & 4.2 & 89.1 & 64.3 & 102.2 \\
1995 & 8.5 & 5.1 & 3.4 & 88.5 & 64.5 & 94.0
\end{tabular}

Sources: EPA, ARNA; Ministry of Finance, Foreign Trade Returns.

Notes:

$X$ : exports (f.o.b.)

$M$ : imports (f.o.b).

$P_{X}$ : export price index.

$Y:$ GDP.

$N X: X-Y$.

$P_{M}$ : import price index

$P$ : GDP deflator.

$e:$ exchange rate (annual average).

(domestic-oriented) firms. The import price index declined even more because of the reverse oil shock and because of the falling yen-dollar rate. Since the terms of trade became increasingly adverse to imported goods, the trade surplus tended to be sustained. Thus, despite (or because of) the depressed economy in the early 1990 s, the trade surplus remained high.

We will next look at changes in the trade composition (see Table 14). Exports fell most conspicuously in the areas of textiles, metal products (iron and steel), and transportation equipment (automobiles). In other words, the traditional export industries have been in a phase-out stage. In contrast, general and electrical machinery both expanded their shares of exports, being Japan's growth industries in recent years.

Turning to the import side, we find that there has been a remarkable increase in the importation of manufactured goods since 1980, especially in the late 1980s. This expansion must be discounted somewhat though because the reverse oil shock made petroleum very cheap, thereby raising the share of manufactured imports. ${ }^{35}$ However, individual items on the importation list indicate that manufactured imports are becoming more important over time, especially textile products, machinery (office machinery, semiconductors, electrical parts, automobiles, scientific instruments, etc.) and miscellaneous products. 
Table 14

The Composition of Japan's Merchandise Trade (f.o.b.)

Total

Foods

Textile materials

Chemicals

Nonmetal materials

Metal products Iron/steel

Machinery

General

Electrical

Transport

Automobiles

Precision

Miscellaneous
Total

Manufactured goods

Foods

Textile materials

Metal materials

Other crude materials

Fuels Crude petroleum Chemicals

Textile products

Nonmetallic products

Metallic minerals

Machinery/precision

Miscellaneous

\section{Exports}

\begin{tabular}{rrrr}
1980 & 1985 & 1990 & \multicolumn{1}{c}{1995} \\
\hline 100.0 & 100.0 & 100.0 & 100.0 \\
1.2 & 0.7 & 0.6 & 0.5 \\
4.7 & 3.6 & 2.5 & 2.0 \\
5.0 & 4.4 & 5.5 & 6.8 \\
1.4 & 1.2 & 1.1 & 1.2 \\
15.8 & 10.5 & 6.8 & 6.4 \\
11.4 & 7.7 & 4.4 & 4.0 \\
60.2 & 71.8 & 74.9 & 74.7 \\
13.4 & 15.8 & 22.1 & 24.1 \\
13.8 & 16.9 & 23.0 & 25.6 \\
25.4 & 28.0 & 25.0 & 20.2 \\
17.2 & 19.6 & 17.8 & 12.0 \\
4.6 & 4.9 & 4.8 & 4.7 \\
7.8 & 7.7 & 8.5 & 8.2
\end{tabular}

Imports

\begin{tabular}{rrrr}
1980 & 1985 & 1990 & \multicolumn{1}{c}{1995} \\
\hline 100.0 & 100.0 & 100.0 & 100.0 \\
22.8 & 31.0 & 50.3 & 59.1 \\
10.4 & 12.0 & 13.4 & 15.2 \\
1.7 & 1.7 & 1.1 & 0.5 \\
8.0 & 4.8 & 3.9 & 2.8 \\
9.2 & 7.5 & 7.1 & 6.4 \\
49.8 & 43.1 & 24.2 & 15.9 \\
37.5 & 26.7 & 13.5 & 8.9 \\
4.4 & 6.2 & 6.8 & 7.3 \\
2.3 & 3.0 & 5.5 & 7.3 \\
0.8 & 1.0 & 2.3 & 1.9 \\
4.6 & 4.3 & 6.2 & 5.0 \\
7.6 & 10.5 & 18.4 & 27.4 \\
11.4 & 15.2 & 26.0 & 26.5
\end{tabular}

Source: Ministry of Finance, Gaikoku boeki gaikyo [Foreign Trade Returns]. 
Table 15

Foreign Assets and Liabilities, as a Percent of GDP

\begin{tabular}{lrrrrrl} 
& & & & \multicolumn{3}{c}{ FDI } \\
\cline { 2 - 6 } & FA & \multicolumn{1}{c}{ FL } & NFA & out & in \\
\cline { 2 - 7 } 1970 & 9.9 & 7.6 & 2.3 & 0.7 & 0.5 \\
1975 & 12.1 & 10.1 & 1.5 & 1.9 & 0.4 \\
1980 & 16.1 & 14.9 & 1.2 & 2.0 & 0.3 \\
1985 & 34.7 & 24.4 & 10.3 & 2.9 & 0.3 \\
1990 & 64.8 & 53.4 & 11.4 & 7.0 & 0.3 \\
1995 & 52.4 & 38.4 & 14.0 & 5.7 & 0.4 \\
U.S. 1995 & 46.2 & 56.9 & -10.7 & 7.9 & 14.1
\end{tabular}

Sources: Japan: EPA, ARNA; United States: ERP, February 1996, Table B-105.

Notes:

FA: Foreign assets $\quad$ NFA: Net foreign assets

FL: Foreign liabilities $\quad$ FDI: Foreign direct investment

Investment income (another important entry in the current account) has been in a net surplus reflecting Japan's rising net foreign asset balance. Table 15 shows Japan's foreign assets and liabilities as a percent of the GDP between 1970 and 1995. The 1980s were the decade in which Japan made a big splash in the international field. Toward the end of this decade, Japan became the largest net creditor in the world.

Japan's net foreign asset balance rose from a mere 1 percent of the GDP in 1980 to 10 percent by 1985 . The latest (1995) was 14 percent. Foreign direct investment going out from Japan increased remarkably in this period, but foreign direct investment into Japan remained minuscule. Japan remained as closed to investment in the 1990s as it was in the 1970s.

Japan provides a good contrast with the United States. Both countries are involved in many foreign transactions, but in foreign direct investment the two countries differ markedly. While Japan is almost totally closed to foreign direct investment, the United States is wide open. That is, the United States continues to be a paradise for foreign investors, while Japan remains as secluded as Shangri-La. It is very difficult to do business with Japan-as many foreign businessmen complain. This is nowhere clearer than in foreign direct investment. If Japan is going to participate in the global world economy, it must open up its domestic market and invite foreign direct investors into the country. 
Figure 1

The Foreign Exchange Market

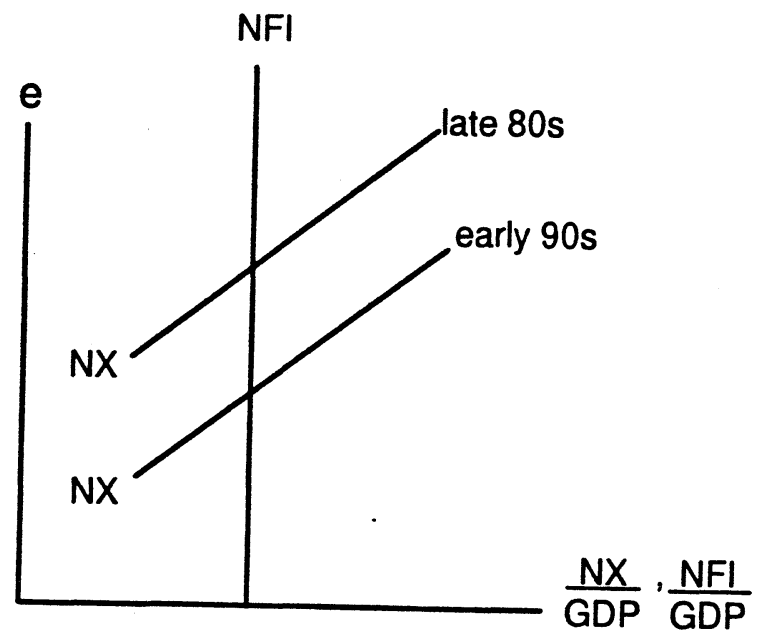

\section{The IS Balance}

The most important and the most succinct representation of a macroeconomy is its IS balance, which is represented by:

Domestic Foreign

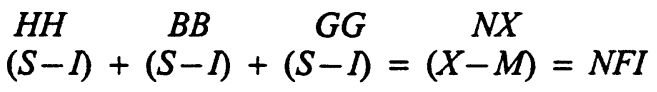

Equation (2)

where $H H$ is the household sector, $B B$ the business (corporate) sector, $G G$ the general government, and $N X$ net exports. $S$ is savings, $I$ investment, and $N F I$ net foreign investment. ${ }^{36}$ Table 16 gives the IS balance for $1985-94$ as percent of GDP.

In reading this table, note that the Japanese economy was on a cyclical upswing between November 1986 and February 1991. Thus, the growth rate was relatively high between 1988 to 1990 . This business cycle had the most noticeable impact on the IS balance of the business sector. Its investment is sensitive to the business cycle, but its savings is not. The business sector's borrowing from the rest of the economy peaked in 1989-91.

The household sector's IS balance, on the other hand, has been relatively stable. Since the mid-1970s, the national government ran in a deficit. However, its strenuous efforts to maintain a zero-growth budget ceiling finally paid off in the late 1980s. Since 1987 the general government has had a budget surplus, 
Figure A-1

The Values of MRD for a Given $Z_{1}>0$

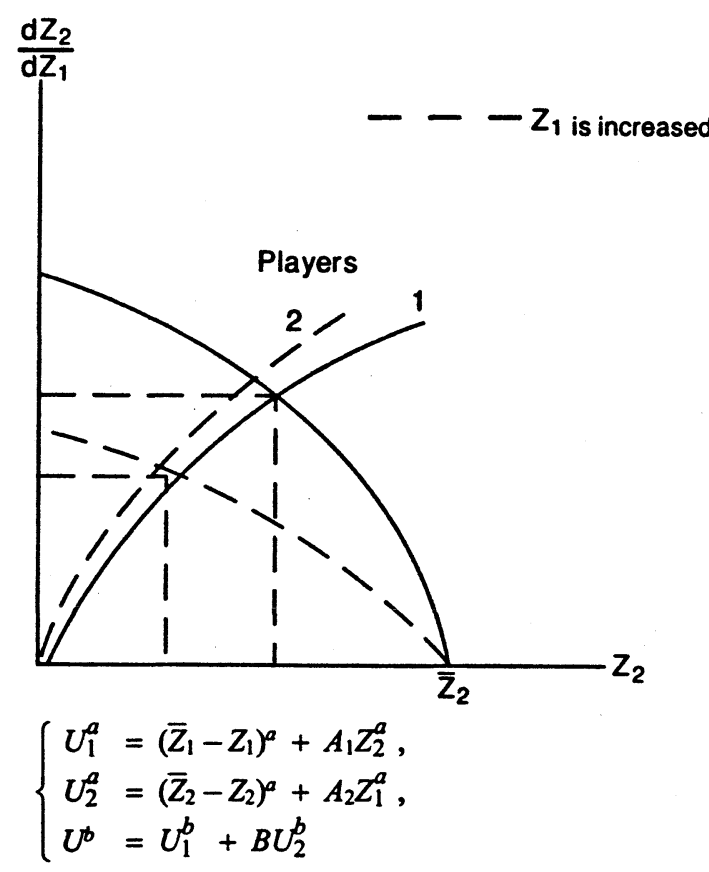

where $a<1, b<1$, and $A$ and $B$ are non-negative. The $M R S$ is derived as follows:

$$
\frac{d Z_{2}}{d Z_{1}}= \begin{cases}\frac{1}{A_{1}}\left(\frac{\bar{Z}_{1}-Z_{1}}{Z_{2}}\right)^{a-1} & \text { for Player 1, } \\ A_{2}\left(\frac{Z_{1}}{\bar{Z}_{2}-Z_{2}}\right)^{a-1} & \text { for Player } 2 .\end{cases}
$$

The $M R S$ is illustrated in Figure $\mathrm{A}-1$. One $Z_{2}$ corresponds to one $Z_{1}$ when the marginal rates of substitution are equated.

The trade-off locus of $\left(Z_{l}, Z_{2}\right)$ is illustrated in Figure A-2. It is represented by:

$$
\left(\frac{\bar{Z}_{1}}{Z_{1}}-1\right)\left(\frac{\bar{Z}_{2}}{Z_{2}}-1\right)=\left(A_{1} A_{2}\right)^{1 /(a-1)} .
$$

The locus moves inward as $\left(A_{1} A_{2}\right)$ is reduced. In the limit, for $A_{1} A_{2}=0$, the locus coincides with the two axes. It is obvious that the optimal point in this case is the origin (i.e., the no-trade point). Thus, the size of $\left(A_{1} A_{2}\right)$ represents the willingness by the two players to give and take. As we move down the locus, $d Z_{2} / d Z_{1}$ or the relative shadow 
Table 16

The IS Balance, 1985-95, Percent of GDP

\begin{tabular}{|c|c|c|c|c|c|c|c|c|c|c|c|c|}
\hline & & 1985 & 1986 & 1987 & 1988 & 1989 & 1990 & 1991 & 1992 & 1993 & 1994 & 1995 \\
\hline Households' & $\begin{array}{l}S \\
1 \\
s-1\end{array}$ & $\begin{array}{r}14.9 \\
5.5 \\
9.4\end{array}$ & $\begin{array}{r}14.7 \\
5.4 \\
9.3\end{array}$ & $\begin{array}{r}13.2 \\
5.4 \\
7.8\end{array}$ & $\begin{array}{r}12.4 \\
4.8 \\
7.6\end{array}$ & $\begin{array}{r}12.5 \\
4.5 \\
8.0\end{array}$ & $\begin{array}{r}11.9 \\
3.8 \\
8.1\end{array}$ & $\begin{array}{r}12.5 \\
5.0 \\
7.5\end{array}$ & $\begin{array}{r}12.6 \\
5.7 \\
6.9\end{array}$ & $\begin{array}{r}13.0 \\
7.5 \\
5.5\end{array}$ & $\begin{array}{r}13.2 \\
7.7 \\
5.5\end{array}$ & $\begin{array}{r}13.3 \\
5.6 \\
7.7\end{array}$ \\
\hline Businesses 2 & $\begin{array}{c}S \\
1 \\
S-1\end{array}$ & $\begin{array}{r}12.0 \\
17.1 \\
-5.1\end{array}$ & $\begin{array}{r}12.3 \\
16.5 \\
-4.2\end{array}$ & $\begin{array}{r}13.2 \\
17.1 \\
-3.9\end{array}$ & $\begin{array}{r}13.2 \\
19.1 \\
-6.0\end{array}$ & $\begin{array}{r}12.6 \\
20.9 \\
-8.3\end{array}$ & $\begin{array}{r}12.7 \\
22.5 \\
-9.8\end{array}$ & $\begin{array}{r}12.6 \\
21.0 \\
-8.4\end{array}$ & $\begin{array}{r}12.9 \\
18.5 \\
-5.6\end{array}$ & $\begin{array}{r}13.5 \\
15.8 \\
-2.3\end{array}$ & $\begin{array}{r}12.7 \\
13.4 \\
-0.7\end{array}$ & $\begin{array}{r}13.6 \\
15.4 \\
-1.8\end{array}$ \\
\hline Domestic & $\begin{array}{c}s \\
1 \\
s-1\end{array}$ & $\begin{array}{r}31.7 \\
28.2 \\
3.5\end{array}$ & $\begin{array}{r}31.7 \\
27.5 \\
4.2\end{array}$ & $\begin{array}{r}32.8 \\
28.4 \\
4.4\end{array}$ & $\begin{array}{r}33.2 \\
30.1 \\
3.1\end{array}$ & $\begin{array}{r}33.5 \\
31.3 \\
2.2\end{array}$ & $\begin{array}{r}33.5 \\
32.3 \\
1.2\end{array}$ & $\begin{array}{r}34.1 \\
32.1 \\
2.0\end{array}$ & $\begin{array}{r}33.8 \\
30.8 \\
3.0\end{array}$ & $\begin{array}{r}32.7 \\
29.7 \\
3.0\end{array}$ & $\begin{array}{r}31.4 \\
28.7 \\
2.7\end{array}$ & $\begin{array}{r}30.6 \\
28.5 \\
2.1\end{array}$ \\
\hline & $g(Y)$ & 4.4 & 2.9 & 4.2 & 6.2 & 4.8 & 5.1 & 3.8 & 1.0 & 0.3 & 0.6 & 1.4 \\
\hline
\end{tabular}

Source: EPA, ARNA, 1997.

Notes:

1. Households + nonprofit organizations.

2. Financial institutions + nonfinancial corporations.

3. Domestic $(S-I), N X$, and $N F I$ differ by statistical discrepancies. 
which peaked in 1990-91. Note that this increase in the government surplus was not the result of a countercyclical measure, but it turned out that the government budget surplus nicely complemented the increase in the business sector's funds demand.

Finally, in 1993, the national government realized that it had to take action concerning the depressed economy. The national government started to use deficit spending, which continued into 1996. As a result, the outstanding balance of government debt started to rise from a bottom of 48.1 percent of the GDP in 1991 to nearly 70 percent in 1996. Thus Japan has become one of the most indebted countries as far as government debt is concerned. (At the height in 1987, the ratio was 55.5 percent.) After the fact, the government's fiscal policy turned out to be quite countercyclical.

Since the business sector's and the government sector's IS balances tended to offset each other, fluctuations in the domestic IS balance were minimized. This domestic surplus can be equated with $N X$ and $N F I$. How these three values are equated to one another depends, among other factors, on what happens in the foreign exchange market.

For simplicity, suppose for the time being that the domestic surplus flows automatically into the country's NFI. In the foreign exchange market, this NFI would be equated with the $N X$, a value determined in the international trade market. While both imports and exports of goods and services depend on many factors, the exchange rate is no doubt the most important equilibrating variable under the flexible exchange rate regime.

Using current values, exports respond positively and imports negatively to the yen-dollar exchange rate. The net export curve then is sloped upward in Figure 1. Using the simplified assumption that the domestic surplus is independent of the exchange rate, $N F I$ is represented by a vertical line in Figure 1. The exchange rate is determined at the intersection of the $N F I$ and the $N X$ curves. The reverse oil shock in the 1980s made imports much cheaper than exports. This resulted in a shift to the right of the $N X$ curve. As long as the $N F I$ curve remains unchanged, the exchange rate must fall. This is what happened in the early 1990 s. $^{37}$

\section{The Financial System and the Bubble}

Real growth slowed down beginning in the mid-1970s, but financial growth accelerated during the slow growth period, eventually ending in a stock-market and land-market bubble of tremendous magnitude in the late 1980s. The depressed condition of the Japanese economy in the early 1990s may be considered as a recuperation from the bubble's ill effects. Details of the bubble and its collapse are described and analyzed in several of my papers (Sato 1995a, 1995b, 1997a, 1997b), of which the following is a summary.

We begin our story with the two Great Ratios observed in Japan's financial 
economy over the last four decades. These ratios are $F / M$ and $L / M$, where $F$ is the economy's total financial asset balance, $L$ the total land value, and $M$ the money balance, all at current values. Both ratios have stayed around their respective long-run levels of 4.0 and 2.0 (Sato 1997). ${ }^{38}$ They, however, greatly deviated upward during the two bubbles of the early 1970s and the late 1980s.

The other side of the money balance is bank loans $(B L)$, which are also a part of the financial asset balance and roughly equal to the money balance in size. It may be better to consider $M+B L$ for the denominator. Then, $F /(M+B L)$ and $L /(F+B L)$ tend to converge at the long-run values of 2.0 and 1.0 , respectively.

$M+B L$ is connected with the banking sector, so the remainder of $F$ is mostly nonbanking financial assets including government bonds, corporate bonds (though bank debentures are the debt of long-term credit banks), corporate equities, life insurance reserves, trade credits, and so forth. The long-run stability of $F /(M+B L)$ at 2.0 means that the economy somehow divides its financial asset balance in roughly equal proportions between bank and nonbank assets.

To explain why such long-run stability exists in Japan's financial system is beyond the scope of the present writing. Here, let me give an heuristic explanation by taking the household sector as a representative case. Japanese households have continued to save a great deal, a smaller part of which is used to buy real estate and a larger part to acquire financial assets. Households hold 60 percent of their financial assets in the form of money. ${ }^{39} \mathrm{M} / Y$ continues to rise in the portfolios of households. As long as households divide $F$ between monetary and nonmonetary assets in a stable manner, $M / Y$ and $F / Y$ both steadily rise, leaving $F / M$ relatively stable.

$L / M$, or equivalently $L / F$, is also found to be stable in the long run. The value of land is determined mostly by the movement of urban land prices $\left(P_{L}\right)$. As the urban population increased within a small urban area, $P_{L}$ continued to rise relative to the general price level $(P)$. Thus, $L / Y$ tended to rise over time because of the continuously rising $P_{L} / P$ which, in tum, was based on the continuing urbanization and growing real income. New purchasers borrow mortgages for both dwellings and land from financial institutions. The increase in $P_{L}$ then is connected to the increase in the number of mortgages, which are a part of bank loans. The $L / M$ has been stable as a result.

People continue to save and put their savings into bank deposits, postal savings, life insurance, and so on. With the banks creating more deposits, the financial institutions - which receive people's money - make loans and create more financial assets. In this way, $F / Y$ keeps pace with $M / Y$ as both continue to increase. The ongoing financial deepening has resulted in a more rapid expansion of the financial sector than the production sector - a feature which has become more prominent since the Service Revolution began. The keiretsu groups have taken advantage of this opportunity and have diversified themselves into the financial sector. Thus, financial deepening has exerted its impact on all aspects of the Japanese economy.

Bubbles are financial deepening run amok. Asset inflation sets in with a violent rush. Stock prices and then land prices shoot up. Consequently, $F / M$ and 
$L / M$ depart from their long-run levels in an upward direction. A few years later the bubble collapses, and asset deflation takes over. Then $F / M$ and $L / M$ again converge to their former long-run levels. From the beginning to the end, a bubble lasts for several years. The latest bubble was of inordinate strength. Not only did it go extremely high, but also it finished with a bang. Though stock prices seemed to hit bottom in June 1995, urban land prices were still on the descent in the fall of 1996. (In 1995, their fall was 13.5 percent.)

How does a bubble break out? The stock market may tum bullish as the animal spirits of the investors are revived. However, the potential demand turns real in the stock market only if investors have funds to invest. For those funds, investors must depend on credit—credit supplied by banks. An increase in the credit supply is matched by an equal increase in the money supply.

From the early 1980s on, the Bank of Japan had an easy-money policy in order to stimulate the relatively depressed Japanese economy in this half decade. Accordingly, the money supply $(M 2+C D)$ maintained a high rate of expansion. Then, as the economy entered the late 1980s, the money growth rate reached beyond 10 percent for a while, but real GDP growth was around 5 percent and inflation was modest. This, in turn, led to two developments. First, the nominal interest rate started downward from around 1980. The continued decline in the interest rate was one factor in asset inflation. Second, bank credit-which was increasing at a comparable rate with the money supply-poured fuel on the fire starting in the asset markets. In this way, money growth was the principal, if not the initial, cause of the bubble.

What then caused the especially high money growth in the late 1980s? As the money multiplier formula tells us, the starting point of the money supply was the central bank's monetary base. The main part of the monetary base is the currency supply, with the remainder being the required reserves of the member banks. As a percent of the nominal GDP, currency in circulation increased from 7.0 percent in 1985 to 8.9 percent in 1989. In response to the increase in the monetary base, the money supply -in particular the Ml' (the sum of currency, demand deposits, and corporate time deposits)-was increased.

Our quest for the most fundamental cause of a bubble brings us to the central bank's monetary policy - in particular its management of the monetary base. The central bank issues currency (on the debit side of the monetary base), but it cannot simply print bank notes (the common fallacy notwithstanding). The bank must increase the asset side of the monetary base by giving: (a) loans and discounts to member banks (mostly discounts), (b) credit to the government (mostly government bonds), (c) foreign reserve (in the form of foreign exchange certificates issued by the Ministry of Finance), and (d) all the rest. While all four of these items are important in monetary-base management (see Sato 1997b), we highlight here the role of the foreign reserve.

The main target of the central bank's monetary policy is price stability. The rate of domestic inflation is sensitive to changes in import prices, which, in turn, 
depend on variabilities in the exchange rate. When the yen-dollar exchange rate is falling out of line, the central bank wants to prevent an excessive decline in the exchange rate. With this objective in mind, the central bank intervenes in the foreign exchange market. As it buys up foreign exchanges, the central bank's foreign reserve expands. However, this purchase of foreign exchanges must be financed by new currency, so the amount of currency in circulation is increased.

An increase of the foreign reserve in the monetary base (which can be abrupt), and an increase in currency in circulation relative to the nominal GDP occur at the same time when the yen-dollar exchange rate seems to be declining rapidly. These three events have occurred simultaneously three times since 1970: the early 1970s (1971-72), the late 1980s (1987-89), and the early 1990s (1993present). This is shown in Table 17.

Recall that the exchange rate began floating in February 1973, but it was revalued a few times after the Nixon Shock of August 1971. In the late 1980s, the yen-dollar rate began a rapid and deep decline in response to the September 1985 G5 Plaza Accord. Once again, in the early 1990s, while the Japanese economy was still depressed, the yen started to be inordinately strong. The yen-dollar rate broke the $¥ 100 / \$$ barrier in July 1994 and was nearing the $¥ 80 / \$$ level by April $1995(¥ 83.67 / \$)$. The central bank repeated its response by increasing its foreign reserve (which continued into the summer of 1996).

In all three cases, the $C / Y$ ratio rose. The two earlier cases gave rise to bubbles. In the early 1990s, there was no bubble as the economy was too depressed to respond.

Financial deepening has continued for a long time in the Japanese economy and is likely to continue as long as the household sector continues to save in the form of money. Banks and postal savings occupy a prominent position in Japan's financial economy with their combined share of financial assets as high as onehalf. At the center of the financial system, there is the Bank of Japan. Its monetary policy has played a key role in Japan's macroeconomy because bubbles are attributed to how the central bank has managed the monetary base. However, the bank's seemingly good intentions backfired.

The central bank has to play the role of a tightrope walker. On one side, there is the danger of putting the national economy into a recession if it allows a high value for the yen with its depressing effect on Japan's exports. On the other side, there is a danger of causing asset inflation because if the bank attempts to stabilize the yen value. So far, the bank tended to come down on the second side. The financial mess following the latest bubble is the bank's own making.

As the Japanese economy recovers, financial deepening will continue to a higher level. With that, the danger of financial instability will be more intense. This is one systemic risk Japan must face in the future.

As the Japanese economy recovers, financial deepening will continue to a higher level. With that, the danger of financial instability will be more intense. This is one systemic risk Japan must face in the future. 
Table 17

$C / Y, F R / M B$, and $e$

\begin{tabular}{|c|c|c|c|}
\hline Year & $C / Y(\%)$ & $F R / M B(\%)$ & $e(¥ / \$)$ \\
\hline 1969 & 6.9 & 24.8 & 360.0 \\
\hline 1970 & 6.8 & 28.1 & 358.1 \\
\hline 1971 & 7.2 & 67.2 & 347.9 \\
\hline 1972 & 8.1 & 77.8 & 303.2 \\
\hline 1973 & 7.9 & 28.9 & 271.7 \\
\hline 1974 & 8.0 & 27.8 & 292.1 \\
\hline 1975 & 7.8 & 25.1 & 296.8 \\
\hline 1976 & 7.7 & 29.9 & 296.6 \\
\hline 1977 & 7.6 & 38.2 & 268.5 \\
\hline 1978 & 8.0 & 34.6 & 210.4 \\
\hline 1979 & 7.7 & 16.0 & 219.1 \\
\hline 1980 & 7.3 & 23.0 & 226.8 \\
\hline 1981 & 7.2 & 22.6 & 220.5 \\
\hline 1982 & 7.3 & 19.0 & 249.3 \\
\hline 1983 & 7.3 & 19.6 & 237.5 \\
\hline 1994 & 7.4 & 19.1 & 237.6 \\
\hline 1985 & 7.0 & 19.7 & 238.1 \\
\hline 1986 & 7.5 & 20.8 & 168.0 \\
\hline 1987 & 7.9 & 33.8 & 144.5 \\
\hline 1988 & 8.2 & 29.8 & 128.0 \\
\hline 1989 & 8.9 & 19.9 & 138.1 \\
\hline 1990 & 8.7 & 15.9 & 144.9 \\
\hline 1991 & 8.3 & 8.7 & 134.6 \\
\hline 1992 & 7.8 & 7.5 & 126.6 \\
\hline 1993 & 8.3 & 10.6 & 111.1 \\
\hline 1994 & 8.5 & 14.7 & 102.3 \\
\hline 1995 & 9.6 & 21.6 & 94.0 \\
\hline
\end{tabular}

Sources:

$C$ : Currency in circulation at end of year, BOJ, ESA.

$F R$ : Foreign reserve at end of year, $\mathrm{BOJ}, E S A$.

$M B$ : Monetary base at end of year, BOJ, ESA.

$Y$ : GDP in calendar year, EPA, $A R N A$.

$e: ¥ / \$$ exchange rate, annual average, Toyo Keizei, Keizai tokei nenkan. 


\section{Notes}

1. Japanese-English dictionaries invariably translate miai marriages as "(an) arranged marriage" or "marriage by arrangement." These translations do not convey the correct meaning of the term.

2. The survey also shows that the average prenuptial period increased from 1.97 years in 1972-73 to 2.97 years in 1992 indicating that people involved in "love" marriages took more time to know each other better, one reason why people now marry later.

3. In the prewar period, divorces were unilaterally from the man's side. The so-called mikudarihan (literally, three lines and a half) is a summary letter of divorce the husband gave to the wife ostensibly for such reasons as she had not "adapted to the ways of the family."

4. Of those firms which enforce mandatory retirement, those setting the retirement age at fifty-five and those at sixty were equal at 39.7 percent in 1980 . The percentage of the former retirement age continued to fall and the latter continued to rise through the $1980 \mathrm{~s}$. By 1993 the proportions were 9.7 percent and 80.0 percent (Ministry of Labor, Survey on Employment Management).

5. The LFPR of females aged sixty-five and over is 16 percent. In the United States, the LFPR for males and females sixty-five and over is 16.8 percent and 8.8 percent (1995). In Western Europe, they are much below 10 percent.

6. Mandatory retirement age was set at fifty-five before World War II when life expectancy at birth was barely above forty years.

7. Female workers with ranks of subsection chiefs or higher increased from 2.5 percent of all workers (both male and female) in 1985 to 4.2 percent in 1995 (JETRO, Nippon, 1997, p. 124). However, by 1995 , female employees in managerial positions were still only 1.0 percent of all female employees as opposed to 11.4 percent in the United States (1993) (ibid., p. 125, based on Ministry of Labor).

8. The percentage of college graduates finding jobs at graduation reached a peak of 81.3 percent in 1991 for both males and females. This rate then started to decline and reached 68.7 percent for males and 63.7 percent for females in 1995. In some cases, those who were not hired for jobs attended graduate schools but most (particularly females) stayed home. Graduates of graduate schools also found it difficult to obtain jobs (in 1995, 67.3 percent for masters and 62.6 percent for doctorates) (Yomiuri Shimbun, November 5,1995 ).

9. The stagnant economy of the early 1990s depressed the labor demand. Consequently, the LFPR declined from 78.0 percent in 1993 to 77.6 percent in 1995 for males and from 50.7 percent in 1992 to 50.0 percent in 1995 for females. Thus workers who would have entered the labor market were discouraged by the lack of labor demand. Assuming that the decline in the LFPRs was involuntary, I estimate the number of discouraged workers to be $0.19 \mathrm{mn}$ (male) and $0.39 \mathrm{mn}$ (female) in 1995. If they were added to the labor force, the unemployment rate would have risen from 3.10 percent to 3.56 percent (male) and from 3.22 percent to 4.60 percent (female) in 1995. The female LFPR rose from 45.9 percent in 1975 to 50.7 percent in 1992. If this upward trend was extrapolated to 1995, the female LFPR would have been 51.9 percent in 1995 . The number of discouraged female workers would then be raised from $0.39 \mathrm{mn}$ to $1.05 \mathrm{mn}$. Thus the female unemployment rate could be considered to be as high as 6.78 percent in 1995 .

10. The number of legal aliens working in industry was 93,775 (December 1994). The breakdown was 61 percent in manufacturing and 20 percent in services (JETRO, Nippon, 1996, p. 131).

11. Foreign spouses living in Japan were 0.5 percent of the number of all marriages in Japan in 1994. 
12. The six keiretsu groups are Mitsui, Mitsubishi, Sumitomo, Fuyo, Sanwa, and Daiichi-Kangin. In terms of total assets, they are roughly equal in size, ranging between 15 percent and 18 percent of the group total. For details, see Fair Trade Commission (FTC), annual reports on the six keiretsu groups after 1987.

13. The Sanwa group has only three financial institutions since it lacks marine and fire insurance; the Daiichi-Kangin group has five financial institutions (one city bank, two life insurances, and two marine and fire insurances).

14. Within the keiretsu groups, manufacturing as a percent of nonfinancial was total assets (54 percent), sales (38 percent), and employment (82 percent) in 1992 (see FTC 1994).

15. Before this period, from August 1945 to November 1955, there were seven prime ministers, but Shigeru Yoshida, the president of the Liberal Party, served two terms for a total of seven years (one year, May 1946-May 1947; six years, two months, October 1948-December 1954).

After this period, from August 1993 to today, there have been four prime ministers: Morihiro Hosokawa (7 months, August 1993-March 1994), Tsutomu Hata (3 months, April 1994-June 1994), Tomoichi Murayama (one year, seven months, June 1994-December 95), and Ryutaro Hashimoto (January 1996 to the present). When the LDP lost the majority in the July 1993 general election, several political parties (which later merged into the Shinshinto or New Frontier party) formed a coalition government. The first head of this government was Hosokawa, who resigned prematurely when he was threatened with a possible impeachment for his ten-year-old scandal. Hata succeeded him but the arrangement did not last. In June 1994, the LDP talked the JSP and another party into a coalition to take over the cabinet. Murayama, the chairman of the JSP, was put forward for premiership as a compromise although the JSP had lost heavily in the July 1993 general election. The LDP supplied the vice premier. After taking care of the aftereffects of the Great Hanshin Earthquake of January 1995, Murayama expressed political fatigue and resigned in early January 1996. Hashimoto, who was elected to the presidency of the LDP in the same month, assumed premiership.

16. In this, the role played by Shin Kanemaru, vice president of the LDP, is important. He was a powerful, behind-the-scenes manipulator of Japanese politics and aptly called the "don" of the LDP or "the shogun in the dark." He controlled the Takeshita faction, the largest in the LDP. He colluded with major construction firms to help them win publicwork projects and concealed a large sum of money received as bribes in his secret bank accounts. His illegal acts were discovered and he was indicted in 1992. His resignation from the LDP was one of the causes of the splintering of the Takeshita faction. Kanemaru died in April 1996 in infamy.

17. One such industry is the parcel delivery service which started to expand rapidly in the 1980s. One of the rising firms in this industry gave bribes to a wide range of politicians including Prime Minister Hosokawa when he was governor of Kumamoto Prefecture ten years ago.

18. Transparency International (Berlin) collected expert opinions about the reputations of individual countries and tabulated them into index numbers (ranging from 0 for corrupt to 10 for honest). Of the forty-one countries in the sample, the least corrupt was New Zealand (9.55). The most corrupt were Indonesia (1.94) and China (2.16). Japan stood exactly in the middle of the list at 20th out of 41 (6.62). The United States was 15th (7.79). Above Japan, most were developed countries, the exceptions being Singapore (3rd, 9.26), Chile (14th, 7.94), and Hong Kong (17th, 7.12). Below Japan, most are developing countries, except for Italy $(33,2.99)$, Greece $(30,4.04)$, Spain $(26,4.35)$, and Portugal $(22,5.56)$. See New York Times, August 20, 1995.

19. From 1981 to 1993, there were four councils: Temporary (March 1981-March 
1983), First (June 1983-September 1986), Second (April 1987-April 1990), and Third (October 1990-October 1993).

20. The Commission is called the Economic Reform Study Group and is headed by Gaishi Hiraiwa, the president of Keidanren (Federation of Economic Organizations). The Commission submitted two reports (referred to as the Hiraiwa Reports), one on deregulation (November 1993) and another on economic reform (December 1993). The reports are reprinted in Nakatani and Ohta (1994).

21. Interim reports show that the pace of deregulation has been slow.

22. The September 1992 projection was based on the fertility rate of 1.8. But the rate fell to 1.42 in 1995 . The Ministry of Welfare revised its population projection downward based on this lower rate (January 1997). In the new projection, the medium version (on which Table 9 is based) assumes that the fertility rate will stabilize at around 1.4. The population will increase from 125.6 million (1995) to the peak of 127.8 million (2007) and then fall to 120.9 million (2025) and 100.5 million (2050). However, if young females continue to postpone marriage, the fertility rate will go down farther. The low version assumes it to go down to around 1.3. The population will peak at 127.1 million (2004) and then go down to 117.5 million (2025) and 92.3 million (2050). See Toyo Keizai, Keizai tokei nenkan (1997), 600-605. The dismal picture of population aging, portrayed in Atoh (1996 for the 1992 projection), applies even more forcibly to the new projection

23. By firm size we have the following for 1995 :

\begin{tabular}{|c|c|c|}
\hline \multirow{2}{*}{$\begin{array}{c}\text { Firm size } \\
\text { (employment) }\end{array}$} & \multicolumn{2}{|c|}{ Paid holidays } \\
\hline & Authorized & Actually taken \\
\hline $\begin{array}{l}\text { Total } \\
\text { More than } 1,000 \\
100-999 \\
30-99\end{array}$ & $\begin{array}{r}7.2 \\
18.7 \\
16.8 \\
15.2\end{array}$ & $\begin{array}{l}9.5 \\
1.0 \\
8.7 \\
7.9\end{array}$ \\
\hline
\end{tabular}

Source: JETRO, Nippon, 1997, p. 123, based on Ministry of Labor.

24. As is well known, total-factor-productivity (TFP) growth is measured by the growth rate of $T$ in the aggregate Cobb-Douglas production function.

$$
Y=T K^{a} N^{1-s}
$$

where $Y$ is real output, $K$ capital stock, and $N$ labor force. Hence:

$$
g(T)=(1-a) g(Y / N)-a g(K / Y) .
$$

We take labor productivity growth $g(Y / N)$ as a proxy for TFP growth. As

$$
g(Y / N)=\frac{1}{1-a} g(T)+\frac{a}{1-a} g(K / Y),
$$

$g(Y / N)$ fails to reflect $g(T)$ correctly if $a$ is not constant or if $g(K / Y)$ is not 0 . Both were violated in the early 1970 s. From 1970 to $1975, K / Y$ rose from 1.08 to 1.47 for all industry and $a$ (operating surplus / NDP at factor cost) fell from 53 percent to 41 percent.

25. Whether government output is correctly measurable in real terms or not is a methodological issue in national accounting.

26. The labor input ought to be manhours $(N H)$ rather than the number of persons $(N)$. Table 10 shows that $H$ rose in 1955-60, declined in 1960-75, rose in 1975-80, constant in 1980-85, and declined in 1985-94. 
27. The revised national accounts of Japan start at 1955.

28. In terms of manhours, productivity growth was positive.

29. Since $g\left(Y_{i} / N_{i}\right)$ aggregates into $g(Y / N)$, we should have:

$$
\sum d_{i} \theta_{i} \equiv 1, \quad \sum d_{i} \theta_{i} \equiv 0
$$

where $\theta_{i}$ is the value added share. In the present case, applying the 1982 values of $\theta$ $(0.041,0.429,0.520)$, we find the two sums to be 0.941 and 0.0035 .

30 . It was generally believed (in 1996) that the equilibrium exchange rate was $¥ 110$ $120 / \$$.

31. For the former, EPA, Price Report, 1995; for the latter, OECD, National Accounts, 1961-1994 (1996).

32. For Japan, see JSYB, 1996, Table 15-11. For the United States, see SABUS, 1991, Table 774 (Cost of living index for Nassau-Suffolk, New York was 159.3 in 1990 relative to nation $=100$ ).

33. The weights for tradables and nontradables are set at 0.1 and 0.9 .

34. See EPA, "Survey on Domestic-Foreign Price Differentials," November 1994. The exchange rate was $¥ 102 / \$$.

35. The average crude oil price fell from $\$ 35.5$ per barrel in 1980 to $\$ 13.8$ in 1988 and was $\$ 17.2$ in 1995 (IMF, International Financial Statistics Yearbook, series 001).

36. The IS balance of the general government is equal to the government surplus.

37. Though we have pretended that the domestic surplus and $N X$ shift independently of each other, this is an oversimplification as far as oil shocks are concerned. During oil crises imported materials (petroleum) become relatively more expensive than domestic goods. As imported materials are embodied in domestic finished goods, the economy must spend more on imports. This shifts $N X$ to the left. On the other hand, domestic consumer goods which embody imported materials are priced higher and domestic consumers must spend more and reduce saving. Thus the domestic surplus is shifted to the left as well. Since the domestic surplus which equals the $N F I$ is likely to shift less than the $N X, e$ is to increase. This is what happened during the two oil crises of 1973-74 and $1979-80$.

38. Another Great Ratio is $K / Y$, where $K$ is the net fixed capital stock. The level of the net fixed capital stock has been relatively stable except for a one-time jump in the early 1960 s.

39. Household deposits with deposit money banks are 53 percent of the total deposits and 64 percent of the total time deposits (1995). However, their bank loans are less than 20 percent of all bank loans, 70 percent of which are mortgage loans. 